\title{
Review \\ Reactive Oxygen Species Induced Pathways in Heart Failure Pathogenesis and Potential Therapeutic Strategies
}

\author{
Aušra Mongirdienè ${ }^{1, *(\mathbb{C})}$, Laurynas Skrodenis ${ }^{2}$, Leila Varoneckaite ${ }^{2}$, Gerda Mierkyte ${ }^{2}$ and Justinas Gerulis ${ }^{2}$ \\ 1 Department of Biochemistry, Medical Academy, Lithuanian University of Health Sciences, Eiveniu str. 4, \\ LT-50161 Kaunas, Lithuania \\ 2 Medical Academy, Lithuanian University of Health Sciences, Mickevičiaus str. 9, LT-44307 Kaunas, Lithuania; \\ laurynas.skrodenis@stud.lsmu.lt (L.S.); leila.varoneckaite@stud.lsmu.lt (L.V.); \\ gerda.mierkyte@stud.lsmu.lt (G.M.); justinas.gerulis@stud.lsmu.lt (J.G.) \\ * Correspondence: ausra.mongirdiene@lsmuni.lt or ausra.mongirdiene@mail.com; Tel.: +370-837361768
}

Citation: Mongirdienè, A.; Skrodenis, L.; Varoneckaitè, L.; Mierkytè, G.; Gerulis, J. Reactive Oxygen Species Induced Pathways in Heart Failure Pathogenesis and Potential Therapeutic Strategies. Biomedicines 2022, 10, 602. https://doi.org/ 10.3390/biomedicines10030602

Academic Editor: Gianluca Baldanzi

Received: 14 January 2022

Accepted: 2 March 2022

Published: 3 March 2022

Publisher's Note: MDPI stays neutral with regard to jurisdictional claims in published maps and institutional affiliations.

Copyright: (C) 2022 by the authors. Licensee MDPI, Basel, Switzerland. This article is an open access article distributed under the terms and conditions of the Creative Commons Attribution (CC BY) license (https:// creativecommons.org/licenses/by/ $4.0 /$ )

\begin{abstract}
With respect to structural and functional cardiac disorders, heart failure (HF) is divided into HF with reduced ejection fraction (HFrEF) and HF with preserved ejection fraction (HFpEF). Oxidative stress contributes to the development of both HFrEF and HFpEF. Identification of a broad spectrum of reactive oxygen species (ROS)-induced pathways in preclinical models has provided new insights about the importance of ROS in HFrEF and HFpEF development. While current treatment strategies mostly concern neuroendocrine inhibition, recent data on ROS-induced metabolic pathways in cardiomyocytes may offer additional treatment strategies and targets for both of the HF forms. The purpose of this article is to summarize the results achieved in the fields of: (1) ROS importance in HFrEF and HFpEF pathophysiology, and (2) treatments for inhibiting ROS-induced pathways in HFrEF and HFpEF patients. ROS-producing pathways in cardiomyocytes, ROS-activated pathways in different HF forms, and treatment options to inhibit their action are also discussed.
\end{abstract}

Keywords: heart failure with reduced ejection fraction; heart failure with preserved ejection fraction; reactive oxygen species; protein kinases; $\mathrm{NO}$; cGC

\section{Introduction}

With respect to structural and functional cardiac disorders, chronic heart failure $(\mathrm{CHF})$ is classified into heart failure (HF) with reduced ejection fraction (HFrEF) and HF with preserved ejection fraction (HFpEF). The most common cause of HFrEF is cardiomyocyte loss due to ischemia. HFpEF is a heterogeneous syndrome with multiple different conditions that can contribute differently to the syndrome [1]. Patients with HFpEF make up more than $50 \%$ of all HF patients $[1,2]$. In recent decades, understanding of the pathophysiology and treatment of HFrEF has increased [3,4]. However, treatment options for patients with HFpEF are few [1]. The main therapeutic target for patients with HFrEF is the neuroendocrine chain with therapies including inhibitors of the renin angiotensin-aldosterone system, mineralocorticoid receptor antagonists, $\beta$-receptor blockers, and medications that increase the half-life of natriuretic peptides [5]. HFpEF treatment relies on addressing the reasons for the observed syndrome, including treating the underlying disease, blood pressure control, use of diuretics and addressing other factors that contribute to development of HFpEF [1].

Oxidative stress (an imbalance between the increased formation of reactive oxygen species (ROS) and the elimination or neutralization of ROS by an antioxidant system) plays an important role in the development of CHF [6] and correlates with left ventricle (LV) dysfunction and hypertrophy in the failing heart [7]. Therefore, pharmacologically targeting specific ROS and pathways induced by them, could be beneficial for CHF patients. Broad and detailed knowledge of the particular sources and formation of ROS, as well as their elimination in the cell, is required in order to better understand the ROS induced 
pathways. Therefore, we have sought to summarize results achieved in the fields of: (1) ROS significance for HFrEF and HFpEF pathophysiology, and (2) treatment options in the management of ROS-induced pathways in the human heart for both HFrEF and HFpEF patients.

\section{ROS Sources, Importance and Danger in Human Cells}

ROS are chemically reactive molecules that belong to a group of nine major types of free radicals. These molecules have an unpaired electron in the superoxide anion $\mathrm{O}_{2}{ }^{-}$, which is unstable. Several compounds are termed ROS, including: free radicals (superoxide anion $\left(\mathrm{O}_{2}^{-}\right)$), the hydroxyl radical $(\cdot \mathrm{OH})$ ) and oxidative agents (e.g., hydrogen peroxide $\left(\mathrm{H}_{2} \mathrm{O}_{2}\right)$, peroxynitrite $\left(\mathrm{ONOO}^{-}\right)$, hypochlorite $\left.\left(\mathrm{OCl}^{-}\right)\right)$[8,9]. $\mathrm{H}_{2} \mathrm{O}_{2}$ is involved in the Fenton reaction in the presence of $\mathrm{Fe}^{2+}$ to produce $-\mathrm{OH} . \mathrm{O}_{2}{ }^{-}$and $\mathrm{H}_{2} \mathrm{O}_{2}$ can produce $-\mathrm{OH}$ through the Haber-Weiss reaction [10]. $\mathrm{ONOO}^{-}$is produced in the reaction of $\cdot \mathrm{NO}$ with $\mathrm{O}_{2}^{-}$[11] (Figure 1) and is known to contribute to chronic heart failure (CHF) pathogenesis [12].

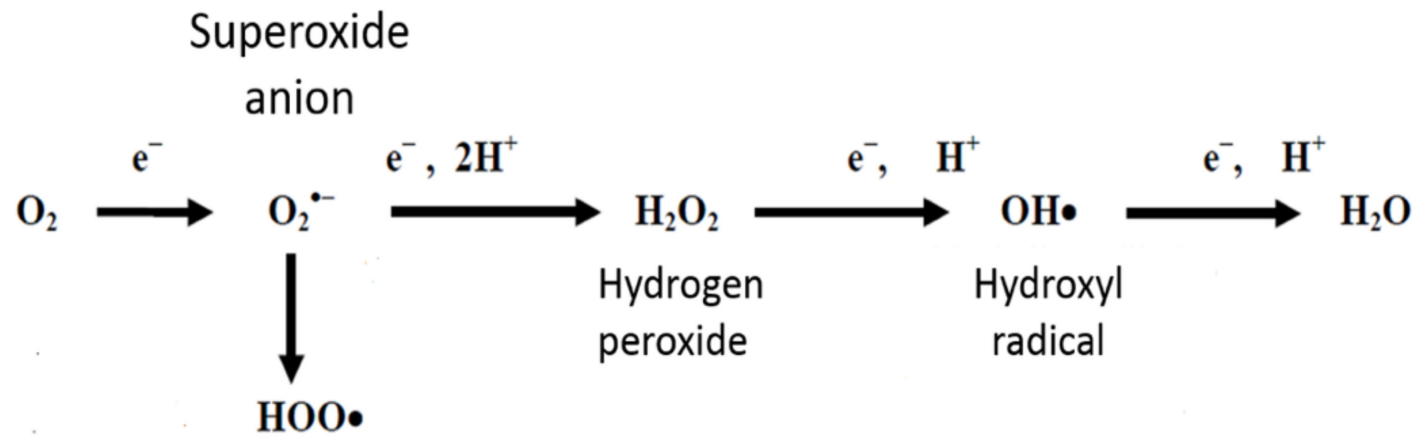

Hydroperoxyle radical

$$
\begin{aligned}
& \mathrm{O}_{2}^{-}+\mathrm{H}^{+}+\mathrm{H}_{2} \mathrm{O}_{2} \rightarrow \mathrm{O}_{2}+\mathrm{OH}^{-}+\mathrm{H}_{2} \mathrm{O} \\
& \text { (Haber - Weiss reaction) }
\end{aligned}
$$$$
\mathrm{Fe}^{+2}+\mathrm{H}^{+}+\mathrm{H}_{2} \mathrm{O}_{2} \rightarrow \mathrm{Fe}^{+3}+\mathrm{OH}^{-}+\mathrm{H}_{2} \mathrm{O}
$$$$
\text { (Fenton reaction) }
$$

Figure 1. Reactive oxygen species. $\mathrm{O}_{2}{ }^{\bullet-}$-superoxide anion, $\mathrm{OH}^{\bullet}$-hydroxyl radical, $\mathrm{H}_{2} \mathrm{O}_{2}$-hydrogen peroxide, $\mathrm{HOO}^{\bullet}$-hydroperoxyle radical, $\mathrm{H}_{2} \mathrm{O}$-water.

The agents referred to are produced in the cells by the mitochondria and enzymes, such as lipoxygenases and cyclooxygenases, under normal conditions [13]. Some processes, such as apoptosis, immune system reactions, differentiation, activation of several transcriptional factors, cellular signaling pathways and induction of a mitogenic response require the presence of some ROS [14]. ROS signaling is either reversible and oxidative or produces reactive nitrogen species. $\mathrm{O}^{2 \bullet-}$ takes part in signal transmission by: (1) causing post-translation redox modifications of proteins [15], (2) hydroxylation (addition of an $\mathrm{HO}$ group) [16], and (3) S-nitrosylation (oxidation of cysteine by NO) [17]. By these means, the reactivity, stability and conformation of the affected molecules is altered [17]. The superoxide anion and hydrogen peroxide are the main ROS that participate in redox signaling [18] (Figure 1). Hydroxyl radicals are more reactive and less specific and reversible [19]. Cell antioxidant enzymes, including superoxide dismutase, catalase, and glutathione peroxidase, protect the cell from ROS excess [20]. ROS excess is known to give rise to oxidative stress, which affects subcellular organelles, changes intracellular enzyme activity, creates intracellular $\mathrm{Ca}^{2+}$ overload and modulates gene expression [21,22]. In turn, cell lipids, proteins and deoxyribonucleic acid (DNA) are damaged, leading to impairment of normal cell function [22] (Figure 2). 


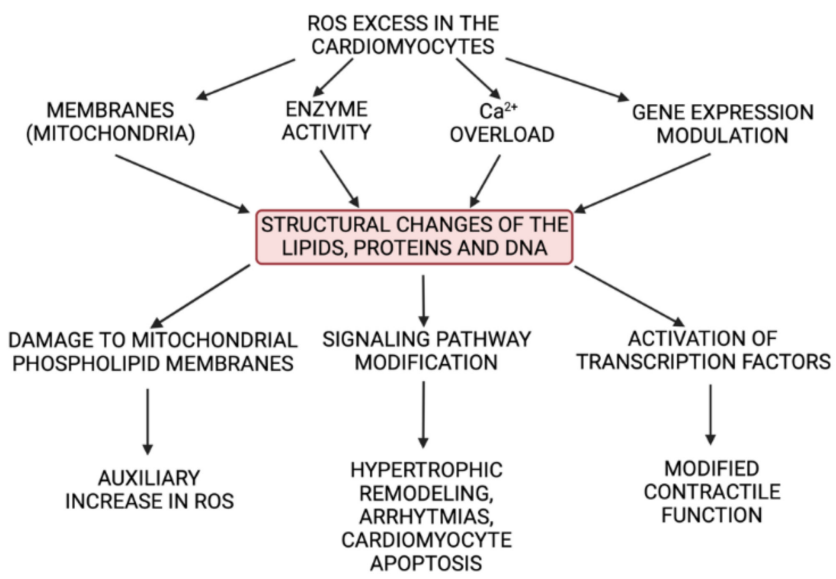

Figure 2. Harmful effects of ROS in cardiomyocytes (created with BioRender.com on 11 February 2022).

ROS, as reported in the literature, activate the signal kinase and transcription factors that modify the function of intracellular proteins and signaling pathways in the heart and in this way contribute to the hypertrophic remodeling of the heart $[23,24]$. Additionally, ROS damage mitochondrial phospholipid membranes and, as a consequence, induce mitochondrial oxidative stress, leading to molecular mechanisms that contribute to the development and progression of heart failure [25].

\section{ROS in the Pathogenesis of CHF Development}

Being a by-product of aerobic metabolism, ROS are abundant in the cells of the myocardium and, if the balance between ROS production and antioxidant systems is impaired, they can greatly contribute to, or worsen, HF [26].

The proteins involved in redox signaling are protein kinase $G(P K G)$ [27], the small G protein Ras [28], Ca/calmodulin-dependent protein kinase II (CaMKII) [29], protein kinase A (PKA) [30], class II histone deacetylases (HDACs) [31], matrix metalloproteinase (MMP) [32], protein kinase B/Akt [33], the extracellular signal-regulated kinase 1/2 (ERK1/2) [34], p38 MAP kinase [35], protein kinase C (PKC) [36], NF-kappa B [37], and transcription factors, including activated protein-1 [38].

Cardiomyocyte hypertrophy has been found to be associated with ROS activation of signaling kinases and transcription factors [23]. ROS also promotes post-translational modifications that change the function of specific proteins and signaling pathways, leading to hypertrophic remodeling $[23,39]$. ROS have been shown to be important in $G$ protein-coupled receptor stimulation by angiotensin II, tumor necrosis factor- $\alpha$ (TNF- $\alpha$ ), and $\alpha$-adrenergic stimulation $[23,40,41]$. Angiotensin II may participate in myocardial hypertrophy by several intracellular pathways by activating: (1) protein kinase C, (2) c-Jun N-terminal kinase (JNK), (3) extracellular signal-regulated kinase, and (4) ROS formation $[40,42]$. Though the role of TNF- $\alpha$ in cardiomyocytes is not yet sufficiently known, TNF- $\alpha$ seems to play an autocrine or paracrine role in activating MMPs, which promote hypertrophic changes in the heart [41].

ROS affect different lipid membranes too, including the sarcolemma, mitochondrial membranes, nuclear membrane, and the sarcoplasmic reticulum, in which lipid radicals and lipid hydroperoxide (LPH) form $[25,43,44]$. As the lipid peroxidation cascade progresses, $\mathrm{LPH}$ reacts with fatty acids to form a more stable product, for example-malondialdehyde or 4-hydroxy-2-nonenal [45]. Destabilization of the phospholipid-rich inner mitochondrial membrane by peroxidation results in additional electron leakage and increase in ROS production intensity $[43,45]$.

ROS activate the cardiac $\mathrm{Na}^{+} / \mathrm{Ca}^{2+}$ exchanger, which triggers cardiac hypertrophy through the $\mathrm{Ca}^{2+}$-dependent pathway [46] and contributes to $\mathrm{Ca}^{2+} /$ calmodulin-dependent protein kinase II activation, leading to increase in cardiomyocyte death and CHF devel- 
opment [47]. The cardiac $\mathrm{Na}^{+} / \mathrm{H}^{+}$exchanger (NHE1) was shown to be activated [48] and sarcolemmal $\mathrm{Na}^{+} / \mathrm{K}^{+}$ATPase was found to be suppressed by ROS [49] and to be implicated in cardiac hypertrophy. It should be emphasized that the elevation of $\mathrm{Na}^{+}$in cardiomyocytes may contribute to slower cardiac muscle relaxation and arrhythmias [50].

It should also be mentioned that heme oxygenase (HO) (an enzyme that catalyzes heme degradation) has been shown to reduce oxidative stress in cardiomyocytes by catalyzing the carbon monoxide $(\mathrm{CO})$ producing reaction $[50,51]$. $\mathrm{CO}$ has been shown to act as an antioxidant and contribute to the anti-hypertrophic effect [51].

Additionally, ROS induced endothelial damage [52,53] and thrombosis development [54] are stated in the literature to take place in chronic HF development.

\subsection{Enzymes Involved in ROS Production}

NADPH oxidases (NOX) 2 and 4 [55], xanthine oxidoreductase (XOR) [56], and nitric oxide synthase (NOS) [57] are the common enzymes that produce ROS in cardiomyocytes (Figure 3).

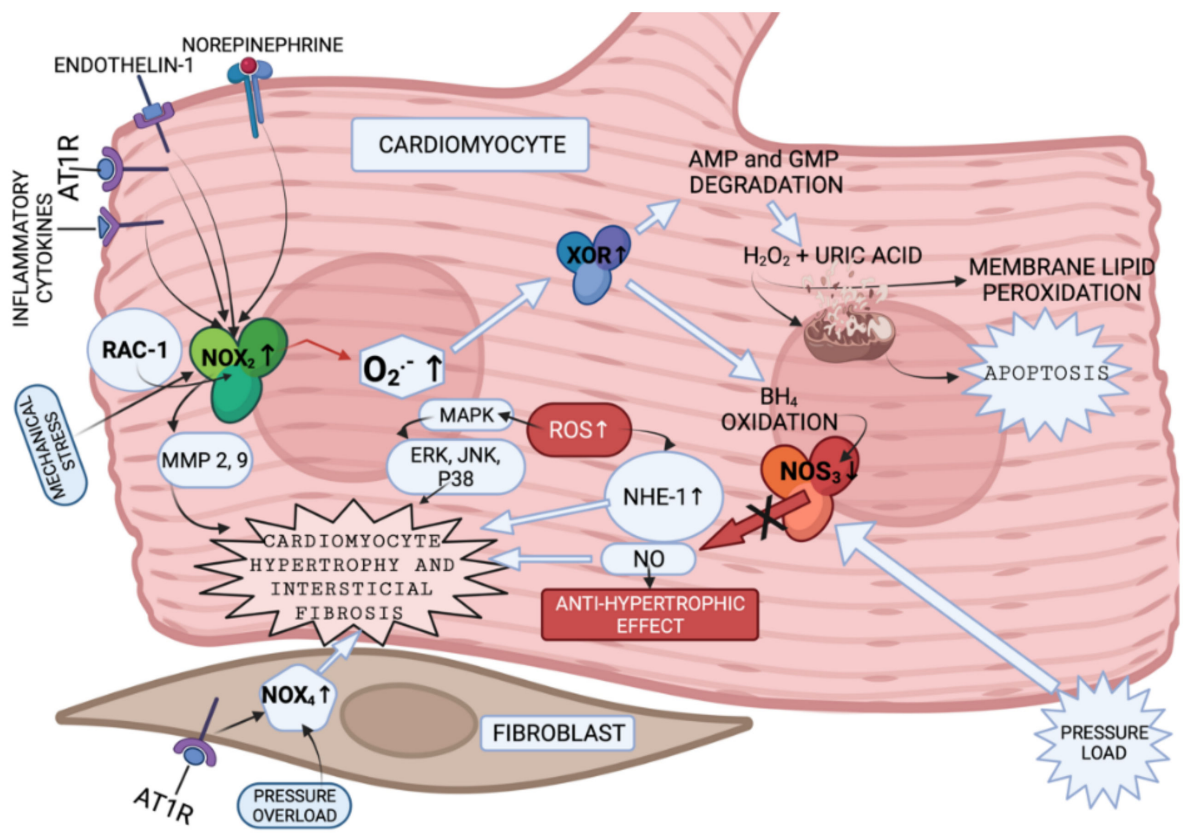

Figure 3. Enzymes involved in ROS production in cardiomyocytes and fibroblasts (created with BioRender.com on 7 February 2022). NOX2 is presented to be activated by endothelin and angiotensin II [58], by cytokines [59] and mechanical stress [60]. Increased NOX2 activation leads to cytoskeletal dysfunction in patients with CHF [61]. It was discovered that superoxide anions, produced by NOX, can oxidize and degrade hydrobiopterin-4 (BH4) leading to NOS uncoupling [62]. Nitric oxide synthase 3 (NOS3) uncoupling was observed in myocardium exposed to chronic pressure load. NOS3 catalyzes nitric oxide (NO) synthesis under physiological conditions. NO has an antihypertrophic effect. However, NOS3 is uncoupled with pressure load, and this, in turn, leads to reduction in tetrahydrobiopterin- 4 concentration, increase in ROS production, and, as a consequence, to cardiomyocyte hypertrophy [63]. It was also shown that increase in ROS activates MAPK, leading to increased expression of proteins, such as ERK, JNK and P38, which are related to cardiomyocyte hypertrophy [64] (Figure 3). What is more, NOX-derived ROS may activate XOR [65]. Additionally, angiotensin II-induced signaling and isolated cardiomyocyte hypertrophy are dependent on NOX2 [66]. GTP-binding protein Rac-1 (involved in NOX activation), as described in the literature, is involved in isolated myocyte hypertrophy, induced by endothelin I, phenylephrine, angiotensin II [67] and norepinephrine [68]. AMPK—adenosine monophosphate activated protein kinase; 
AT1R—angiotensin II receptor; NOX-NADPH oxidase; BH4—dihydrobiopterin-4; NOS—nitric oxide synthase; NO—nitric oxide; MAPK—mitogen-activated protein kinase; XOR—xanthine oxidoreductase; AMP—adenosine monophosphate; GMP—guanosine monophosphate; Rac-1—GTP-binding protein; NHE-1—sodium/hydrogen exchanger-1; ERK—extracellular signal-regulated kinase; JNKc-Jun N-terminal kinase; p38 - a focal point of interactions of the serine/threonine kinases), MMPmatrix metalloproteinase.

Humans have seven NOX with a similar catalytic core, but different regulatory mechanisms [19]. NOX2 and NOX4 are abundantly expressed in cardiomyocytes, endothelium and fibroblasts. Every NOX produces the superoxide anion [62]. NOX2 and NOX4 activity is presented in Figure 3. The data presented in $[69,70]$ implies that NOX4-derived ROS could contribute to overload-induced LV hypertrophy (LVH), and that NOX2 is produced in response to angiotensin II infusion. However, some studies suggest that LVH, as a response to chronic renin-angiotensin-aldosterone system activation, is not associated with NOX2 [71,72]. The enzymes involved in ROS production in cardiomyocytes and fibroblasts, and the pathways that they activate according to the literature [58-68], are presented in summary in Figure 3.

NOX has been shown to be involved in MMP activation in response to angiotensin II [73] and mechanical stretch [71] in the vessels. Experiments with mice and rats have demonstrated the role of NOX2 in the development of interstitial cardiac fibrosis, however, the NOX2-expressing cell type was not established [71,72,74]. NOX4 was shown to be expressed in cardiac fibroblasts $[75,76]$ in animal models. Currently there are no in vivo experiments that could confirm the analogous case in humans.

The other ROS produced enzyme is XOR. XOR is involved in: (1) degradation of the purine nucleotides (AMP and GMP), in which it oxidizes hypoxanthine and xanthine to uric acid and $\mathrm{H}_{2} \mathrm{O}_{2}$ [77], (2) reduction of nitrite and nitrate, in which it produces $\mathrm{NO}$ and consequently promotes vasodilatation [78], or inflammation [78] and mitochondrial damage (as a result of overproduction) [79]. There are two forms of XOR: xanthine dehydrogenase and xanthine oxidase (XO). XO is involved in $\mathrm{H}_{2} \mathrm{O}_{2}$ production [80]. High levels of uric acid are found in patients with $\mathrm{HF}$ blood tests [77]; therefore, production of $\mathrm{H}_{2} \mathrm{O}_{2}$ is expected to be increased in these patients as well.

NOS catalyze NO production in a reaction where L-arginine is converted to L-citruline [81]. There are three isoforms of NOS. Two isoforms of NOS (endothelial (eNOS) and neuronal (nNOS)) are expressed more intensely in cardiomyocytes [82]. However, iNOS can contribute to contractile damage in CHF as well [83].

Increased ROS production is related both to myosin-activated protein kinase (MAPK) [64] (Figure 3) and adenosine monophosphate activated protein kinase (AMPK) activation [84]. AMPK activation leads to an increase in the antioxidants SOD and catalase (CAT) and uncoupling of protein 2 (UCP2) gene expression, leading to weakened apoptosis and NOX expression decrease [84] (not shown in Figure 3).

Another group of enzymes involved in CHF development through ROS production. is a family of NAD+ dependent class III histone deacetylases called sirtuins (SIRT) [85]. There are seven members of this enzyme group in different cell departments. SIRT3 is found in the mitochondria [86] and is involved in ATP production and ROS detoxication [87,88]. Some studies have found that SIRT3 is involved in cardiac muscle hypertrophy and fibrosis, leading eventually to CHF development $[89,90]$. Additionally, some studies have found that SIRT3 is involved in oxidative stress-mediated cell death in cardiomyocytes through protein $\mathrm{Ku} 70$ deacetylation, leading to deacetylated $\mathrm{Ku} 70$ interaction with the apoptosis regulator bcl-2-like protein4 (Bax) [91]. However, other studies have highlighted several mechanisms through which SIRT3 exerts a cardioprotective effect: (1) SIRT3 activates the antioxidant enzyme superoxide dismutase (SOD) [92], and (2) activates isocitrate dehydrogenase 2 (IDH2) by deacetylation. IDH2 uses NADP+ for reduction. SIRT3, in this way, increases NADPH levels, and increases glutathione (GSH) levels, thereby, inhibiting ROS production [93]. 
It can be concluded that several redox-signaling pathways may be modulated by ROS-producing enzymes, leading to cardiomyocyte hypertrophy, interstitial fibrosis and apoptosis. The value of NOX seems to be far more important in comparison with the other enzymes in that its activation can be triggered by both neuroendocrine factors and pressure overload, or by inflammatory cytokines. NOS play an important role in redox alterations in CHF development, both with substrates and cofactors. Sirtuins are involved in the enzyme-antioxidant activation that protects the heart from hypertrophy. NOX-, XOR-, NOS- and SIRT-mediated pathways could, therefore, be potential treatment targets for CHF development suppression.

\subsection{Mitochondria in ROS Production and Enzyme-Antioxidants}

The most abundant source of ROS in cells is the mitochondrial electron transport chain (ETC). A total of $0.2-2 \%$ of the electrons in the ETC leak out of the chain and interact with oxygen to produce superoxide or hydrogen peroxide [47]. Additionally, $\mathrm{H}_{2} \mathrm{O}_{2}$ is produced in the reaction, catalyzed by SOD1. After it has diffused from mitochondria, $\mathrm{H}_{2} \mathrm{O}_{2}$ is involved in physiological and pathological pathways (damaging proteins and lipids) [47]. $\mathrm{H}_{2} \mathrm{O}_{2}$ damages mitochondrial DNA, interferes with the Krebs cycle, ATP production, and fatty acid metabolism [94] and can trigger the opening of ion channels or the inner membrane anion channel inside the mitochondria, leading to cell death [95]. Proton leakage in the mitochondria consists of: (1) basal leakage (not regulated and related to the inner mitochondrial membrane's lipid bilayer and the adenine nucleotide translocase (ANT)), and (2) inducible leakage (regulated and catalyzed or suppressed by uncoupling proteins and ANT) [47]. UCP2 is involved in cardiovascular disease; therefore, drugs targeting UCP expression or activity might be a potential treatment option. Hypoxia is suggested to further increase ROS production in the mitochondria [47]. ETC complexes III (CIII), and especially I (CI), are found to be the main sites of ROS production [96]. Therefore, the regulation of ROS production in these complexes may yield significant results.

Mitochondrial ROS are also involved in different cell signaling pathways, involving apoptosis [97], autophagy [98], and necrosis [99].

Other ROS sources in the mitochondria are the enzymes monoamine oxidase A and B, both located within the outer mitochondrial membrane (OMM). They catalyze the oxidative deamination of neurotransmitters and biogenic amines, leading to $\mathrm{H}_{2} \mathrm{O}_{2}$ production [100]. Monoamine oxidase A (MAO-A) is specific to cardiomyocytes [101]. It was discovered that MAO-A-dependent ROS formation may impair autophagy, leading to the accumulation of autophagosomes and mitochondrial fusion, resulting in microtubule-associated protein light chain 3-phosphatidylethanolamine conjugate (recruited to autophagosomal membranes) formation, and autophagy receptor (p62) and ubiquitylated protein accumulation, causing cardiomyocyte death and CHF. Both MAO-A derived $\mathrm{H}_{2} \mathrm{O}_{2}$ and aldehydes are able to directly target mitochondrial function [102]. Additionally, MAO-A-generated ROS has been shown to inhibit sphingosine kinase, which leads to ceramide accumulation and, thereby, to cardiomyocyte apoptosis [103]. Contractile proteins (actin and tropomyosin) are also affected [104].

Excess of $\mathrm{H}_{2} \mathrm{O}_{2}$ in the cell is eliminated by glutathione peroxidase (GPX) and peroxiredoxin (PRX). Both of these require GSH and thioredoxin for regeneration [105], which requires NADPH as a cofactor $[105,106]$. Nicotinamide nucleotide transhydrogenase, NADP+-dependent isocitrate dehydrogenase (IDH) and malic enzyme are involved in $\mathrm{NADP}+$ regeneration to NADPH [107]. These require Krebs cycle products-NADH, malate and isocitrate. With IDH being the most important for NADPH regeneration [108], the Krebs cycle is necessary for the antioxidant capacity within mitochondria [109] as well as in the cytosol [110]. Aldehyde dehydrogenase (ALDH2) is another mitochondrial enzyme involved in antioxidant activity and participates in the detoxication of lipid peroxidation products [111]. Moreover, ROS through intermediate links, activate AMPK, leading to an increase in antioxidant enzyme gene expression (SOD, CAT and (UCP2)) [84]. 
In sum, the mitochondria are an important ROS source in cardiomyocytes. The amount of ROS produced by mitochondria depends on the supply of oxygen to the cell and activity of the enzymes that produce ROS (especially SOD1 and MAO-A). Cardiomyocyte cytosol antioxidant GPX and PRX regeneration also depends on Krebs cycle action. AMPK activation is important for antioxidant enzyme function.

\section{Differences in ROS-Induced Pathways between HFrEF and HFpEF}

Abnormalities in antioxidant values and oxidative states are found in CHF of various etiologies. Oxidative stress is increased in both HFrEF and HFpEF and is related to the pathogenesis of myocardial remodeling $[9,21,55,112,113]$. Comparison of oxidative stress readings in ischemic cardiomyopathy and non-ischemic cardiomyopathy patients and the correlations between oxidative stress parameters and clinical readings have highlighted the possibility that the defense mechanisms against ROS could differ between these groups [93].

\subsection{ROS in HFrEF}

HFrEF is considered in patients with an LV ejection fraction lower than $40 \%$ [5]. HFrEF is mostly associated with large scale cardiomyocyte death and formation of eccentric hypertrophy as a result of myocardial infarction, cardiomyopathy or valvular heart disease [114]. Irreversible cardiomyopathic changes, subcellular abnormalities and, in turn, decreased heart systolic-diastolic function are suggested to be the causes of elevated ROS levels in HFrEF [115]. Excess of ROS in HFrEF can participate in: (1) subcellular abnormalities and contractile function damage by proteins involved in excitation-contraction and modification coupling [116], (2) myocardial fibroblast proliferation and MMP activation [115], (3) mitochondrial dysfunction due to upsurge of mitochondrial matrix calcium [117], as well as mitochondrial fragmentation, stimulating cardiomyocytes to undergo apoptosis [118] and decrease in oxidative capacity in HFrEF [119]. Lysosomes are known to take part in active mitophagy of clustered mitochondria [117]. Mitophagy is upregulated and intensified with progression to HFrEF [119] due to peroxidation of the lysosomal membranes and lipofuscin accumulation [120].

The molecular mechanisms leading to mitochondrial clustering have not yet been clarified. An mRNA-binding protein, involved in the proper cytoplasmic distribution of mitochondria, named clustered mitochondria protein homolog (Cluh), has been suggested as a participant in mitochondrial biogenesis and oxidative capacity [121]. Cluh has been found to be downregulated in an HFrEF rat model [122], however, it has not yet been investigated in humans.

Proteins in OMM (mitofusin 1 and 2) [123], the inner mitochondrial membrane (IMM) (optic atrophy 1 (OPA1)) [124], and mitochondrial fission proteins (dynamin-related protein1 (DRP1)) [125] and fission1 [122] are stated to be damaged by ROS [122]. OPA1 was suggested to take part in mitochondrial respiratory efficiency [126], mitochondrial fragmentation and apoptosis [127], and its expression was found to be decreased in HFrEF patients [119]. It was discovered that the mitochondrial mitophagy marker BNIP3 takes part in promoting mitochondrial fragmentation by binding to OPA1, leading to OPA1 inhibition [127]. Additionally, BNIP3 inhibition increases DRP1 phosphorylation leading to its cytoplasmic translocation [117]. DRP1 was also found to be increased in HFrEF patients [119]. It is worth paying attention to mitochondrial dynamic proteins (MDPs) that are regulated by some signaling pathways involving proteasome-dependent degradation and transcription and, therefore, modulating mitochondrial function [128]. It was shown that MAPK phosphorylates MFN2, leading to its degradation, and is therefore important in myocardial remodeling induced by mitochondrial related apoptosis [129,130] (Figure 4).

Troponin I, phospholamban [129] and DRP1 [131] have been shown to be target proteins in PKA-related initiation of remodeling and progression to $\mathrm{HF}$. 


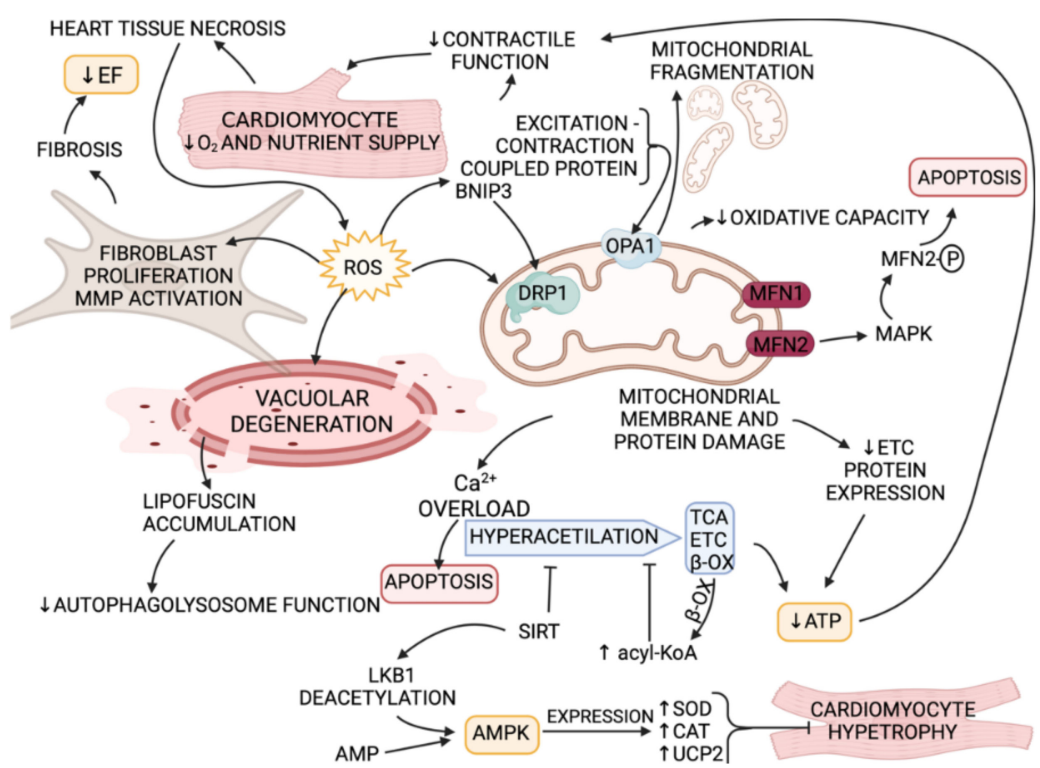

Figure 4. ROS in HFrEF pathogenesis (created with BioRender.com on 9 February 2022). Decrease in $\mathrm{O}_{2}$ and nutrient supply in cardiomyocytes results in ROS overproduction. Increase in ROS leads to MMP activation and consequently fibroblast proliferation, vacuolar degeneration, excitationcontraction coupled protein oxidation (consequently leading to decrease in contractile function of cardiomyocytes) and oxidation of mitochondrial OMM and IMM proteins. OMM protein damage results in MAPK pathway activation, leading to apoptosis. IMM protein OPA1 oxidation (resulting in inhibition) with BNIP3 inhibition by ROS causes mitochondrial fragmentation. Both mitochondrial and other cytosol protein oxidation by ROS lead to decrease in ETC protein expression, resulting in ATP production decrease, resulting in poor contraction. Hyperacetylation of ETC complexes, fatty acid beta-oxidation and TCA cycle proteins lead to inhibition of its activity. SIRT, in healthy cardiomyocytes, inhibits hyperacetylation and activates AMPK-induced pathway, leading to enzymeantioxidant synthesis which leads to hypertrophy inhibition. Excess of ROS inhibits beneficial SIRT effects. (EF-ejection fraction; MMP-matrix metalloproteinase; ROS-reactive oxygen species; BNIP3 - mitochondrial mitophagy marker; OPA1—optic atrophy 1 protein; DRP1—dynamin-related protein 1; MFN2-mitofusin 2; MAPK-mitogen-activated protein kinase; ETC-electron transport chain; $\beta$-OX — beta-oxidation; SIRT—sirtuin family of NAD+-dependent deacetylases; TCAtricarboxylic acid cycle; LKB1—liver kinase B1; AMP—adenosine monophosphate; AMPK—AMP activated protein kinase; SOD—superoxide dismutase; CAT—chloramphenicol acetyltransferase; UCP2-uncoupling protein 2).

Calcium uptake in mitochondria is managed by the voltage-dependent anion channel (VDAC1) at the OMM [132], and is regulated by the mitochondrial calcium uniporter (MCU) at the IMM [133]. Calcium efflux is managed by the sodium/calcium/lithium exchanger at the IMM through intermembranous space, and then through VDAC1 into the cytosol [134]. Mitochondrial matrix calcium overload has been suggested as a major cause of mitochondrial dysfunction and decrease in oxidative capacity in patients with CHF [134], but decrease in MCU expression in HFrEF has also been suggested [135]. Therefore, clarification is needed on how activation of signaling pathways affects calcium flux through the OMM and IMM.

Decrease in oxidative capacity was found to be linked to decreasing expression of ETC complexes, or post-translation modifications of mitochondrial proteins (mainly acetylation) $[117,119,136]$. Cytochrome $C$ oxidase activity was shown to be reduced along with reduction of expression of ETC complexes I and IV [117]. Decrease in ETC complex expression [119] and increase in protein acetylation is present in HFrEF patients [136]. Acetylation of ETC complexes, fatty acid beta-oxidation and tricarbonic acid (TCA) cycle proteins lead to inhibition of its activity [136] (Figure 4). It is speculated that the reason 
behind mitochondrial protein hyperacetylation is related to reduced protein deacetylation by SIRT3 and SIRT5, and excess of acyl-CoA [137]. Both SIRT3 and SIRT5 were found to be downregulated in a rat HFrEF phenotype, but not in a moderate cardiac remodeling setting [122].

Elevated cytoplasmic $\mathrm{Na}^{+}$, abnormal mitochondrial $\mathrm{Ca}^{2+}$ regulation and impaired energy metabolism are additional causes of diminished mitochondrial function in cardiomyocytes. These, in turn, downgrade mitochondrial energy supply and increase mitochondrial ROS release. Increased cytoplasmic $\mathrm{Na}^{+}$impels mitochondrial $\mathrm{Ca}^{2+}$ depletion, mediated by mitochondrial $\mathrm{Na}^{+} / \mathrm{Ca}^{2+}$ exchanger activity. Therefore, qualitatively different patterns of ROS emission across a similar range of $\mathrm{Ca}^{2+}$ concentrations are produced [138].

A positive correlation between serum levels of reactive oxidative metabolites (DROM) and high-sensitivity C-reactive protein (hs-CRP) was shown [139], suggesting interfaces between oxidative stress and inflammation in HFrEF [140].

Post-ischemic condition, hemorrhage, severe trauma or toxic necrosis are the cause of sterile inflammation in HFrEF patients. As a result, endogenous stimuli trigger sterile inflammation by activating receptors, such as cluster of differentiation 36A, initializing the pathogen recognition receptor (PRR), resulting in tissue injury and intracellular cytokine release [141]. Subsequently, PRR triggers type I interferon (IFN), mitogen-activated kinase (MAPK) and nuclear factor kappa-B (NFKB), as a result, increasing pro-inflammatory chemokine and cytokine levels [142]. Therefore, granulopoiesis is induced by hematopoietic stem cells (HSC) that upregulate the production of neutrophils and monocytes [143]. Released neutrophils are conveyed through the blood into the heart where they phagocytose damaged cells. After infiltrating the heart, monocytes produce growth factors (IL-10, TGF $\beta$ ) and cytokines to reduce inflammatory triggering and promote endothelial and smooth muscle cells to initiate scar formation [144]. This pathological event sequence causes cardiac fibroblasts to migrate and proliferate in the injury site where they are transformed into myofibroblasts. Stress fibers are produced by myofibroblasts, which cause interference and propagation of electrical signaling, as well as secretion of profibrotic signaling factors TNF- $\alpha$, TGF- $\beta$ and angiotensin II (Ang II). Together, these factors can induce and modify cardiomyocyte hypertrophy [145]. Moreover, myofibroblasts also line the extracellular matrix, resulting in interstitial and perivascular fibrosis that stiffens the myocardium, inducing collagenous scar formation [145]. Additionally, TNF- $\alpha$ triggers apoptosis in cardiomyocytes through death receptors [146].

Taken together, mitochondrial damage, including enzymes involved in metabolic pathways (such as fatty acid oxidation and the TCA cycle), OMM and IMM proteins, ETC protein acetylation and $\mathrm{Ca}^{2+}$ channels were found to be more related to ROS-induced cardiomyocyte damage and CHF progression in HFrEF patients. Mitochondrial-dysfunction-causing pathways can act simultaneously or subsequently contributing to HFrEF worsening. The possibilities for mitochondrial function improvement will be discussed in the treatment options section.

\section{2. $R O S$ in HFpEF}

HF is defined as impaired LV myocardial contractility, diminished right ventricle (RV) function and decreased left atrium (LA) volumetric and contractile function. Energetic imbalances, interstitial fibrosis, cardiomyocyte hypertrophy, and oxidative stress derived from mitochondrial dysfunction and endothelial dysfunction, are always present in the setting of HFpEF [4,147].

Pro-inflammatory status affects multiple organ systems and contributes to generalized microvascular inflammation with diminished cyclic guanosine monophosphate (cGMP) and nitric oxide (NO) bioavailability, and reduced protein kinase G (PKG) activity. In turn, lessened PKG activity contributes greatly to cardiomyocyte hypertrophy and increased resting tension because of impaired connectin (a protein responsible for elasticity of the muscle) phosphorylation [141]. In addition, increased peroxynitrite concentrations, together with scarce NO availability, facilitate fibroblast proliferation through epidermal growth 
factor, platelet-derived growth factor, phosphatidylinositol 3-kinase and janus kinase pathways. These processes in combination cause stiffened cardiomyocytes and increased collagen deposits, which eventually lead to diastolic dysfunction due to elevated LV pressures in HFpEF [148-150]. Matrix metallopeptidase 9 (MMP9), a tissue inhibitor of MMP1, is also increased in HFpEF [151]. In addition, measured cardiomyocyte length and width were significantly larger in an HFpEF patient group, when compared with an HFrEF patient group [152].

Comorbidities play an important role in the HFpEF setting. Diabetes mellitus, obesity, chronic kidney disease, hypertension and anemia generate a systemic inflammatory setting. For example, in obese HFpEF patients, macrophages in adipose tissue promote secretion of proinflammatory cytokines and, in CHF patients with anemia, low hemoglobin concentration fosters oxidative stress, caused by immune response to iron deficiency [153-155]. A systemic inflammatory state, induced by comorbidities, causes elevated levels of interleukin- 6 (IL-6), tumor necrosis factor $\alpha$ (TNF- $\alpha$ ), soluble ST2 (a receptor that inhibits cardioprotective impact of IL-33), and pentraxin 3 (a complement activator and autoimmunity control agent) $[151,156,157]$. In turn, pro-inflammatory cytokines induce ROS production in the endothelium through NOX [158], causing oxidative and nitrosative stress in the myocardium of HFpEF patients $[159,160]$. Obesity-induced inflammatory cytokines activate ROS production through NOX activation [161]. Decrease in NO has been shown to be highly important in HFpEF development through ROS [141] (Figure 5).

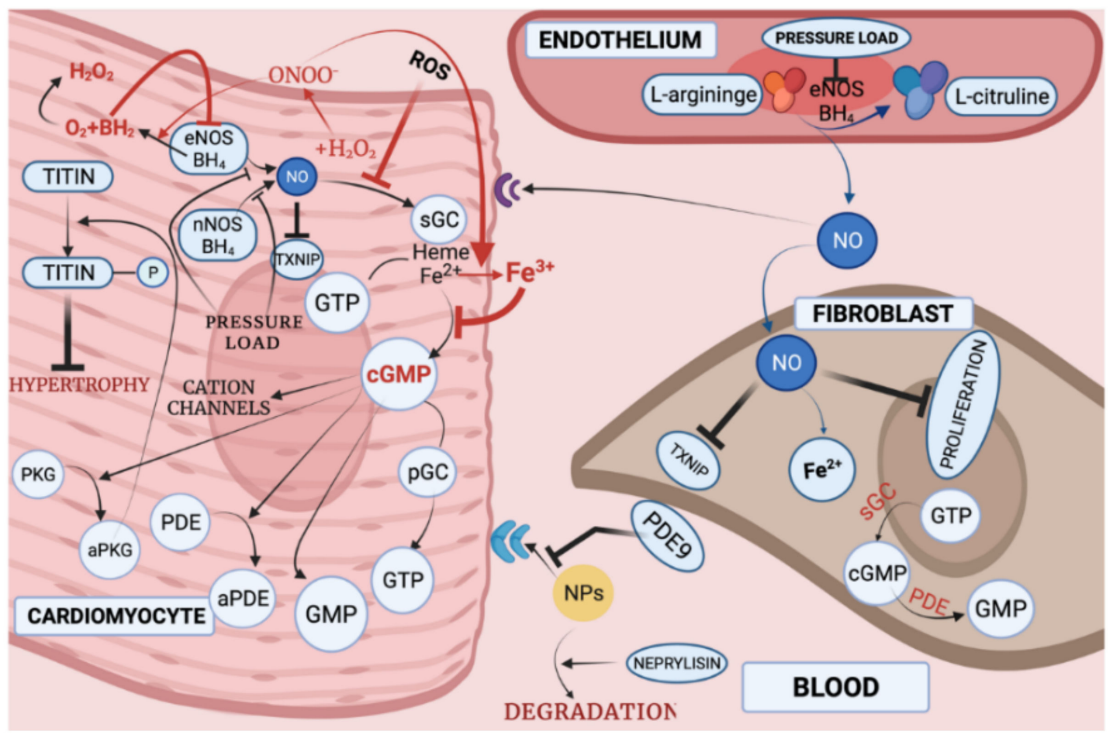

Figure 5. NO-cGMP-PKG pathway in HFpEF development (created with BioRender.com on 9 February 2022). NO, produced in endothelium by eNOS in normal conditions, protects fibroblasts and cardiomyocytes from harmful proliferation. BH4 (hydrobiopterin-4) is required for eNOS action. NO acts via stimulation of cardiac SGC receptors (leading to cGMP synthesis). cGMP regulates phosphodiesterases (PDEs) and cGMP-dependent protein kinases (PKG). NO inhibits TXNIP, resulting in inhibition of apoptosis, however ROS inhibit this action. Oxidative stress shifts sGC towards an oxidized heme-free form which is unresponsive to endogenous and exogenous NO. Titin hypophosphorylation leads to hypertrophy of cardiomyocytes. Increased peroxynitrite concentrations, together with scarce NO availability, induce fibroblast proliferation. Due to uncoupled eNOS, superoxide production increases. In turn, low levels of NO react with superoxide to generate peroxynitrite. Peroxynitrite: (1) oxidizes $\mathrm{BH} 4$ to $\mathrm{BH} 2$ (BH2 inhibits eNOS), and (2) oxidizes $\mathrm{Fe}^{2+}$ to $\mathrm{Fe}^{3+}$ $\left(\mathrm{Fe}^{3+}\right.$ inhibits cGMP production from GTP). Therefore, cGMP cannot activate PKG to phosphorylate titin, whereas titin phosphate prevents cardiomyocyte hypertrophy. For this reason, eNOS inhibition results in both fibroblast and cardiomyocyte proliferation. Neprylisin catalyzes NPs degradation, and PDE9 inhibits NPs. NPs acts through receptors in cardiomyocytes to modulate proliferation 
of cardiomyocytes. NO-nitric oxide, eNOS — endothelial nitric oxide synthase, BH4dihydrobiopterin-4, NPs—natriuretic peptide, PKG—protein kinase G, a-activated, sGC — soluble guanylyl cyclase, pGC - particulate guanylyl cyclase, PDE-GMP—regulated phosphodiesterase, ROS—reactive oxygen species, titin-P—phosphorylated titin, GTP—guanosine triphosphate, TXNIPthioredoxin-interacting protein.

Due to uncoupled eNOS, superoxide production increases. In turn, low levels of NO react with superoxide to generate peroxynitrite, leading to nitration of tyrosine residues and formation of nitrotyrosine [162]. NO seems also to be responsible for early LV relaxation and reduction of end-diastolic stiffness [163]. In addition, NO acts by stimulating cardiac soluble guanylate cyclase (sGC) receptors, leading to cGMP synthesis [164]. Additionally, brain natriuretic peptide (BNP) stimulates particulate guanylate cyclase (pGC) [165]. cGMP is a secondary messenger, operating cGMP-gated cation channels, through cGMP regulated phosphodiesterases (PDEs) and cGMP-dependent protein kinases (PKG) [166]. In HFpEF, NO bioavailability is low due to inflammation and oxidative stress. cGMP concentration and PKG activity reduction was also observed in an HFpEF model. Moreover, oxidative stress shifts sGC towards an oxidized, heme-free form which is unresponsive to endogenous and exogenous NO [167]. Titin hypophosphorylation associated with stiffened cardiomyocytes was also observed in animal models [168,169]. Therefore, ROS are involved in the NO-sGC-cGMP-PKG pathway associated with titin hypophosphorylation and myocardial diastolic stiffness in HFpEF (Figure 5).

Structural vascular abnormalities are another important component in HFpEF pathogenesis. Stiffened arteries contribute greatly to increased pulse pressure and mean arterial and systolic blood pressures [170]. Mellisa A. Lyle et al. investigated contractile protein expression in HFpEF, HFrEF and control group patients and found that the HFpEF group had decreased myosin phosphatase target subunit 1-protein (responsible for NO mediated vasodilation) concentration. The authors, therefore, speculated that this was a possible reason why NO, cGMP or PKG signaling-pathway-targeted pharmacotherapies result in poor clinical benefits [171].

Inducible nitric oxide synthase (iNOS) upregulation is known to be an important factor in the development of HFpEF [172]. iNOS-related nitrosative stress increases s-nitrosylation of inositol-requiring protein $1 \alpha$ (IRE1 $\alpha)$ and decreases transcription factors involved in cellular stress response-spliced X-box-binding protein1 (XBP1s) levels [173]. It should also be mentioned that overexpression of XBP1s in cardiomyocytes weakened the HFpEF cardiac phenotype. It seems that iNOS-mediated nitrosylation of IRE1 $\alpha$ interferes with the XBP1 connection, which is required for the stress response [173]. Therefore, iNOS inhibition can be considered as a therapeutic strategy in the HFpEF setting.

Mitochondria play an important role in CHF, but are less understood in HFpEF pathophysiology [174]. Oxidative metabolism in mitochondria shifts towards a compensatory response through increased glycolysis; however, hypertensive HFpEF models do not seem to have correlation between increased glycolysis and, as a result, increased pyruvate oxidation rates, although it results in significant increase in proton production $[175,176]$. The same process was shown in an HFpEF-induced rat model, which displayed reduced pyruvate dehydrogenase activity, diminished glucose oxidation and increased pyruvate dehydrogenase kinase (PDK4) expression [177]. In obese models, mitochondrial ETC is affected through peak oxidative phosphorylation and NADH-associated respiration. NADH-associated dysfunction can be explained by diminished NADH-linked mitochondrial respiration due to calcium overload [178,179]. Declining energy reserves in the myocardium eventually lead to systolic dysfunction, even if it is "hidden" under a preserved ejection fraction [180].

Phosphodiesterase (PDE) 5 and 9 were shown to be upregulated in hypertrophy and CHF. In addition, PDE9-mediated natriuretic peptide (NPs) regulation in cardiomyocytes was more efficient than with NO-stimulated cGMP regulation [181]. PDE expression in the myocardium of HFpEF was increased and both PDE9 and PDE5 were involved in regulating cGMP-PKG activity [181]. Therefore, PDE9 and PDE5 could be potential treatment targets in patients with $\mathrm{HFpEF}$. 
Taken together, the NO-sGC-cGMP-PKG pathway appears to be the most investigated and important one in HFpEF pathogenesis. This pathway involves overproduction of hydrogen peroxide then initiates titin phosphorylation, leading to cardiomyocyte hypertrophy. Additionally, eNOS inhibition results in fibroblast proliferation. PDE is also involved in the cGMP induced pathway in HFpEF pathogenesis. The NO-sGC pathway has been investigated as a potential treatment target and will be discussed in the treatment strategy section of this article.

\section{ROS-Induced Pathways as a Treatment Target in HFrEF and HFpEF}

There are two interactive elements, related to other factors, that are implicit in the pathogenesis of CHF: inflammation and oxidative stress [182]. Some groups of compounds were investigated for their effect in oxidative stress-induced myocardial damage/remodeling reduction in CHF development including: (1) adenosine monophosphateactivated protein kinase (AMPK) activators, (2) renin-angiotensin system inhibitors (RAAS inhibitors), (3) inhibitors of ROS-producing enzymes, (4) antioxidants, (5) MAO inhibitors, (6) medications that improve mitochondrial function, and (7) substances that increase cGMP-PKG signaling. Each of these groups will be discussed below.

\subsection{AMPK Activators}

AMPK is an enzyme that has a pleiotropic cardioprotective impact and is important in the progression of CHF [84]. There are two AMPK isoforms: $\alpha 1$ and $\alpha 2$, and AMPK $\alpha 2$ seems to dominate in cardiomyocytes [183]. In normal conditions low amounts of ROS activate AMPK through different pathways [184], leading to antioxidant enzyme SOD, CAT and UCP2 gene expression (Figure 4), activation of pathways that produce adenosine triphosphate (ATP), suppression of apoptosis, inhibition of NOX expression and, by these pathways, protection from cardiac hypertrophy [146]. According to data presented above in the section on ROS in HFrEF, it appears that AMPK pathway action could be more feasible for HFrEF. Some drugs, such as metformin, statins, trimetazidine and resveratrol, were reported to have effects on AMPK activation and may prove to be beneficial in the clinical setting for ROS reduction and HF progression dampening [146]. For example, atorvastatin is suggested to activate the eNOS signaling pathway via AMPK, which, in turn controls NO bioavailability, maintains cardiovascular homeostasis and activates AMPK by altering the AMP/ATP ratio or increasing ROS-dependent PKC activity [146]. This process has been shown to attenuate heart dysfunction, fibrosis, and hypertrophy in a post-MI rat model [185]. Trimetazidine activates AMPK by influencing ATP levels in cardiomyocytes, thus improving heart function, New York Heart Association (NYHA) functional class, exercise tolerance and patient's quality of life [186]. Resveratrol is stated to be able to inhibit cardiomyocyte hypertrophy through the AMPK-dependent pathway via two mechanisms: (1) at a high concentration (50-100 $\mu \mathrm{M})$, it can activate AMPK by increasing the AMP / ATP ratio [187]; (2) the SIRT1-LKB1 (one of AMPK upstream activators) pathway [188]. Resveratrol in animal models decreases oxidative stress [189], but clinically it has not yet been thoroughly investigated $[187,188]$. AMPK not only improves energy supply to increase heart function, but also improves heart function by mediating various intracellular physiological functions, delaying myocardial fibrosis, and reducing heart damage in animal models. The benefits of these compounds in clinical studies with $\mathrm{CHF}$ patients appear to be worth exploring.

\subsection{Renin-Angiotensin System Inhibitors}

Angiotensin II (ANG II) is stated to promote excess accumulation of collagen [190] and is involved in ROS production in cardiomyocytes, leading to myocardial remodeling and chronic HF (Figure 4). Cardiomyocyte hypertrophy (induced by ANG II), therefore, could be inhibited by AT1R inhibition. Several potential drugs (e.g., valsartan, candesartan and kaempherol), affecting chronic HF pathogenesis through the ANG II pathway, have been investigated. 
Treatment with valsartan reduced mRNA expression levels of NOX2 and NOX4, as well as the myocardial protein expression levels of NOX2 and NOX4, in rats with doxorubicin-induced myocardial injury [64]. The authors noted that ANG II increased the protein expression levels of NOX2 and NOX3 and the production of ROS, and that protein expression levels of ERK, JNK and P38, which lie downstream of MAPK, were increased as well. It was emphasized that pre-treatment with valsartan reduced the expression of AT1R, NOX2, NIX4 and ROS, therefore, activity of the MAPK signaling pathway was decreased [64]. Clinical studies have confirmed the valsartan effect on oxidative stress reduction through NOX2 in the human myocardium [191] (Table 1).

Table 1. Medicines affecting human cardiomyocytes via renin-angiotensin system in HF patients.

\begin{tabular}{|c|c|c|c|c|c|}
\hline Medicine & Patients & $\begin{array}{c}\text { Appl., Dose and } \\
\text { Duration }\end{array}$ & Results & $\begin{array}{c}\text { Pathophysiological } \\
\text { Mechanism }\end{array}$ & Reference \\
\hline Valsartan & $\begin{array}{c}\text { CHF, NYHA } \\
\text { functional class II-IV, } \\
\qquad n=83\end{array}$ & $\begin{array}{c}\text { 6-week study, } 80 \text { or } \\
160 \mathrm{mg} \text { bid }\end{array}$ & $\begin{array}{l}\text { Produced } \\
\text { hemodynamic and } \\
\text { hormonal effects. }\end{array}$ & $\begin{array}{l}\text { Blocks angiotensin } \\
\text { AT1 receptor } \\
\text { leading to NOX2 } \\
\text { activity reduction. }\end{array}$ & {$[191]$} \\
\hline $\begin{array}{c}\text { Sacubitril/valsartan } \\
\text { (LCZ696) }\end{array}$ & $\begin{array}{c}\text { HFrEF (NYHA II-IV) } \\
\text { and } \mathrm{LVEF} \leq 40 \% \\
n=4822\end{array}$ & 5 years & $\begin{array}{l}\text { Decreased levels of } \\
\text { NT-proBNP or } \\
\text { improved left } \\
\text { atrial volumes. }\end{array}$ & $\begin{array}{c}\text { Inhibits neprilysin/ } \\
\text { ATR }\end{array}$ & [192] \\
\hline Sacubitril/valsartan & $\mathrm{HFrEF}, n=54$ & $\begin{array}{l}\text { Twice a day } 24 / 26, \\
49 / 51,97 / 103 \mathrm{mg}\end{array}$ & $\begin{array}{l}\text { Improved NYHA } \\
\text { class, decreased } \\
\text { NT-pro BNP } \\
\text { concentration, } \\
\text { reduced mortality. }\end{array}$ & $\begin{array}{c}\text { Inhibits neprilysin/ } \\
\text { ATR1 }\end{array}$ & [193] \\
\hline Candesartan & $\begin{array}{l}\mathrm{HFpEF} n=1958, \\
\mathrm{HFrEF}, n=1959\end{array}$ & 2.9 years & $\begin{array}{l}\text { Improved } \\
\text { outcomes in both } \\
\text { groups. }\end{array}$ & ATR1 inhibitor & {$[194]$} \\
\hline
\end{tabular}

Neprilizine is an endopeptidase that cleaves the natriuretic peptides (NPs), bradykinin and adrenomedullin [195]. Inhibition of neprilysin is a main act due to an enhanced effect on biologically active NP. This inhibition increases the plasma concentrations of other vasoactive peptides, including vasodilators, such as adrenomedullin (a peptide associated with the calcitonin gene), bradykinin, and vasoconstrictor peptides, including endothelin1 and angiotensin I and II [195]. Therefore, the AT1R inhibitor valsartan was added to neprilizine (sacubitril). It was discovered that sacubitril/valsartan (LCZ696-combination 1:1 of valsartan and sacubitril) reduced the risk of hospitalization for cardiac failure or death from cardiovascular disease in patients with HFrEF [196]. LCZ696 was also found to reduce plasma $\mathrm{N}$-terminal pro b-type natriuretic peptide (NT-proBNP) concentration in $\mathrm{HFpEF}$ and to reduce the risk of death and hospitalization in HFrEF with EF $\leq 40 \%$ [192]; however, outcomes for HFpEF are not yet established. Therefore, LCZ696 provides a greater protection of target organs than AT1R therapy alone, including cardiovascular protection. This drug is superior in targeting the renin-angiotensin-aldosterone system (RAAS) in patients with HFrEF who can tolerate AT1R inhibitors, with a better safety and efficacy profile [190,192,197]. LCZ696 was well tolerated in a Phase II large HFrEF population [192], produced lower levels of NTproBNP (NCT01920711) and improved NYHA functional class [198,199].

Researchers recently investigated the usefulness of the ATR1 locator candesartan in HFpEF treatment and discovered that candesartan improved outcomes to a similar degree as for HFrEF patients [194].

Current guidelines strongly recommend neurohormonal antagonist treatment for HFrEF [200]. Despite HFpEF patients representing a majority of those with chronic HF in the general population, there are no recommendations for HFpEF treatment with sacubitril/valsartan [201]. 
Kaempherol (KFP, 3,4',5,7-tetrahydroxyflavone) is a flavonoid, found abundantly in plant foods [202], and prevents oxidative stress [203]. KFP was suggested to inhibit cardiac remodeling through deactivation of mitogen-activated protein kinases (MAPKs) [204]. The activation of MAPK is known to promote fibrosis (Figure 3). Additionally, treatment aimed at cardiac fibroblasts with KFP resulted in decreased expression of pro-inflammatory cytokines [204], supplementing the cardioprotective effect. Further clinical studies are needed to determine the suitability of this medication in patients.

\subsection{Inhibitors of ROS-Producing Enzymes}

The mitochondrial and cytosol enzymes NOX, NOS and XOR were discussed as primarily ROS-produced enzymes in cardiomyocytes (Sections 3.1 and 3.2). ETC proteins were suggested as ROS sources as well. One of the compounds related to mitochondrial ETC is Mito-Q - a combination of the triphenylphosphonium cation (TPP) and $\mathrm{Q}_{10}$. This remedy demonstrated promising antioxidative effects in several human studies [205-208]. Mito-Q is $\mathrm{Q}_{10}$ coupled to lipophilic TPP+ and it accumulates on the IMM [205]. $\mathrm{Q}_{10}$, when reduced to ubiquinol by the ETC, acts as an antioxidant, preventing mitochondrial oxidative damage [206] and resulting in heart hypertrophy reduction in an HF rat model [208]. MitoQ is stored in mitochondria in vivo and is a part of the redox system, together with the reduced hydroquinone MitoQuinol form. The pivotal aim of MitoQ is to protect and prevent cellular damage, triggered by mitochondrial ROS overproduction and oxidative stress $[209,210]$. It is important to mention that MitoQ is bound to the mitochondrial IMM, mostly in the hydrophobic membrane core, which is determined by the membrane potential, while the respiratory chain complex II is continuously processed into ubiquinol [211]. The active part of MitoQ is ubiquinone (coenzyme $Q_{10}$ ) [212]. MitoQ was shown to protect against oxidative damage in animal models with HF by reducing hydrogen peroxide formation [207]. Further clinical studies are needed to confirm the analogous effect in larger humans.

NOX-, XOR- and NOS-induced pathway inhibition may be one of the ways to reduce ROS damage in the heart. In small clinical studies, it has been shown that myocardial $\mathrm{O}_{2}$ consumption is lowered and mechanical efficiency of the LV is improved by XOR inhibition [56] due to increased ATP flux through creatine kinase (CK) [213]. XOR inhibitors are known to improve LVEF [214], endothelial function [215], and to decrease BNP levels [216] in HF patients. However, larger studies did not show the same amount of benefit in an HFrEF patient group [217-219].

Inhibition of eNOS and combined treatment with $\mathrm{BH} 4$ also reduced ROS production in animal models with HF [63]. Overexpression of the enzyme catalyzing BH4 biosynthesis (GTP-cyclohydrolase 1) or oral consumption of $\mathrm{BH} 4$ shielded from harmful $\mathrm{Ca}^{2+}$ pathways and contractile dysfunction in isolated cardiomyocytes in vivo mice through nNOS action [220]. However, few clinical studies have investigated the benefits of BH4 usage and the results of these were rather poor.

Taken together, XOR inhibitors have been shown not to be effective in chronic HF patient treatment. Management of NOS activity is still at the research stages. We have not found any studies that investigated the benefits of NOX inhibition or Mito-Q effect in CHF patients.

\subsection{Antioxidants}

Administration of antioxidants (AOx) has been expected to be a simple and effective way to reduce oxidative harm in the myocardium. Vitamin-antioxidants, Mito-TENPO, enzyme-scavengers of ROS and elamipretide were investigated (Table 2). 
Table 2. Antioxidants affecting human cardiomyocytes in chronic HF patients.

\begin{tabular}{|c|c|c|c|c|c|}
\hline Medicine & Patients & $\begin{array}{l}\text { Appl., Dose and } \\
\text { Duration }\end{array}$ & Results & $\begin{array}{c}\text { Pathophysiological } \\
\text { Mechanism }\end{array}$ & Reference \\
\hline OTC OCs & $\begin{array}{l}\text { Patients with heart } \\
\text { failure with preserved } \\
\text { ejection fraction } \\
(\text { HFpEF), } n=16 .\end{array}$ & $\begin{array}{l}600 \mathrm{mg} \text { of } \alpha \text {-lipoic } \\
\text { acid, } 1000 \mathrm{mg} \text { of } \\
\text { vitamin C, and } \\
600 \mathrm{IU} \text { of vitamin } \mathrm{E}\end{array}$ & $\begin{array}{c}\text { Improved } \\
\text { peripheral vascular } \\
\text { function regardless } \\
\text { of changes in } \\
\text { global markers of } \\
\text { oxidative stress in } \\
\text { HFpEF. }\end{array}$ & $\begin{array}{l}\text { Alterations in } \\
\text { redox balance as a } \\
\text { result of } \\
\text { attenuated } \\
\text { endogenous AOx } \\
\text { capacity and/or } \\
\text { elevated oxidative } \\
\text { stress might be an } \\
\text { underlying } \\
\text { mechanism. }\end{array}$ & [216] \\
\hline AOx & $\begin{array}{l}\text { Patients with HFrEF, } \\
n n=14\end{array}$ & $\begin{array}{l}1 \mathrm{~g} \text { of vitamin C, } \\
600 \mathrm{IU} \text { of vitamin } \\
\mathrm{E} \text {, and } 0 \mathrm{mg} / \text { day). } \\
6 \mathrm{~g} \alpha) . \text {-lipoic acid }\end{array}$ & $\begin{array}{c}\text { Improved } \\
\text { macrovascular } \\
\text { function, reduced } \\
\text { oxidative stress, } \\
\text { and increased AOx } \\
\text { capacity in patients } \\
\text { with HFrEF }\end{array}$ & $\begin{array}{l}\text { Changes redox } \\
\text { balance; Increases } \\
\text { oxidative stress; } \\
\text { Decreases } \\
\text { endogenous AOx } \\
\text { protection. }\end{array}$ & [221] \\
\hline
\end{tabular}

Some small studies evaluated vitamin-antioxidants combinations in HFpEF [216] and HFrEF [221] and discovered improvement in peripheral vascular function and decrease in oxidative stress (Table 2). In the first study, reactive hyperemia ( $\mathrm{RH})$, a measure of microvascular function, did not change after OC (combination of $\alpha$-lipoic acid, vitamin $C$ and vitamin E) administration. Improvement in flow-mediated dilation was accompanied by significant increase in plasma nitrite and decrease in CRP, but additional biomarkers of oxidative stress, plasma concentrations of free radicals and antioxidant capacity were not altered by AOx. These findings confirm the efficacy of an over-the-counter OC combination in achieving systemic anti-inflammatory effects and improving peripheral vascular function, regardless of changes in global markers of oxidative stress in $\mathrm{HFpEF}$, providing new insight into the potential therapeutic effect of AOx [216]. The second study of HFrEF patients was characterized by macrovascular endothelial dysfunction, which may be due, at least in part, to a change in redox balance, leading to increased oxidative stress and decreased endogenous AOx protection. The results of this small study showed that chronic AOx administration is a simple way to improve macrovascular function, reduce oxidative stress, and increase AOx capacity in patients with HFrEF [221] (Table 2). However, larger sample studies are needed to properly investigate the beneficial effects of this compound.

Mito-TENPO is a mitochondria-targeted chemical with superoxide-scavenging properties [208]. MitoTENPO was given to prevent and reverse HF [222] and improved LV contraction [223] in a mouse model. Despite these promising results, we did not find any studies performed with $\mathrm{CHF}$ patients.

One more area of AOx application in chronic HF therapy is enhancing ROS scavenging capacity through GSH [224], SOD [225] and catalase [226]. Different chemicals were investigated to increase SIRT3 activity as well [204]. Studies in these fields demonstrated beneficial results, but further investigations are still needed.

Despite increasing interest in oxidative stress management possibilities in CHF patients, most antioxidant therapies are not successful [6,227].

\subsection{MAO Inhibitors}

$\mathrm{MAO}$ are enzymes located on the OMM. They catalyze deamination of biogenic amines and neurotransmitters [102]. The mechanisms of MAO toxicity have been commonly associated with excessive $\mathrm{H}_{2} \mathrm{O}_{2}$ production, due to $\mathrm{MAO}$ appearing to be one of the major ROS sources within the mitochondria [100]. Studies in animal models suggested that activation of MAO-A/B plays a crucial role in progression from cardiac hypertrophy to 
cardiac failure, establishing a clear association between MAO-induced ROS production and mitochondrial dysfunction. However, MAO is suggested as a promising new therapeutic target in chronic diseases [228-235]. Despite the clinical relevance of these findings, and the possible indications for MAO inhibitors in the treatment of chronic HF, little is known about the activity of MAO in HF patients and its association with redox imbalance [236].

\subsection{Mitochondrial Function Improvement}

Mitochondrial function depends mainly on ETC and membrane integrity. Coenzyme $\mathrm{Q}\left(\mathrm{CoQ}_{10}\right)$ is one of the ETC components [237]. Currently, only one clinical study is being conducted to address this aspect of the pathophysiology of HFpEF. A study on $\mathrm{CoQ}_{10}$ in diastolic heart failure patients (NCT03133793) is investigating the efficacy of ubiquinol, a reduced form of $\mathrm{CoQ}_{10}$, which acts to reduce the severity of HFpEF symptoms and improve cardiac function [238].

$\mathrm{CoQ}_{10}$ is an essential cofactor of the ETC from complexes I and II to complex III. It maintains mitochondrial membrane potential, supports ATP synthesis and inhibits ROS generation $[239,240]$. Plasma levels of $\mathrm{CoQ}_{10}$ are decreased in patients with chronic $\mathrm{HF}$, and correspond to the severity of a disease. Doses of $\mathrm{CoQ}_{10}$ have been reported to increase the incidence of adverse reactions at doses above $1200 \mathrm{mg} /$ day, with doses of 22 to $400 \mathrm{mg} /$ day being considered safe [241]. An analysis of small studies suggested that $\operatorname{CoQ}_{10}$ can improve LVEF in HFrEF [242] and can reduce cardiovascular mortality by 50\% [243]. However, it was not sufficiently powerful due to poor prognostic effect [237] for it to be recommended in guidelines [5]. $\mathrm{CoQ}_{10}$ is also needed for eNOS management [235]. CoQ 10 benefits in HFrEF patients are well discussed by A. Sharma and co-authors [237]. It remains unclear if prescribing of $\mathrm{CoQ}_{10}$ is useful due to mitochondrial function improvement, or due to its involvement in eNOS action. The utility of $\mathrm{CoQ}_{10}$ for $\mathrm{HFpEF}$ patients requires further investigation.

Elamipretide is a compound that accumulates in the IMM by binding to cardiolipin [244], a phospholipid, required for proper ETC function and other IMM proteins [244,245]. Cardiolipin can be oxidized by elevated ROS [246] and disturbs interaction of ETC complexes, leading to $\mathrm{O}^{2-}$ increase and apoptosis initiation [247]. Elamipretide improved mitochondrial function in a dog model [248] and isolated cardiomyocytes [249,250]. Despite favorable effects in animal models and isolated cardiomyocytes, the clinical effects in humans with $\mathrm{HF}$ are rather modest (Table 3 ).

Table 3. Medicines affecting human cardiomyocyte mitochondria in chronic HF patients. (LVEDVLV end-diastolic volume, LVESV-LV-end-systolic volume).

\begin{tabular}{|c|c|c|c|c|c|}
\hline Medicine & Patients & $\begin{array}{l}\text { Appl., Dose and } \\
\text { Duration }\end{array}$ & Results & $\begin{array}{c}\text { Pathophysiological } \\
\text { Mechanism }\end{array}$ & Reference \\
\hline $\begin{array}{l}\text { Elamipretide } \\
\text { (SS-31) }\end{array}$ & $\begin{array}{c}\mathrm{HFrEF}(\mathrm{EF} \leq 35 \%) \\
n=24 \text { and placebo } \\
n=12\end{array}$ & $\begin{array}{c}\text { i.v., 4-h infusion } \\
0.25 \mathrm{mg} \times \mathrm{kg}^{-1} \times \mathrm{h}^{-1}\end{array}$ & $\downarrow$ LVESV, $\downarrow$ LVEDV & $\begin{array}{l}\text { By binding to } \\
\text { cardiolipin, } \\
\text { decreases ROS } \\
\text { production. }\end{array}$ & [251] \\
\hline $\begin{array}{l}\text { Elamipretide } \\
\text { (SS-31) }\end{array}$ & $\begin{array}{c}\operatorname{HFrEF}(\mathrm{EF} \leq 40 \%) \\
n=48 \text { and placebo } \\
n=23\end{array}$ & $\begin{array}{l}\text { p.o., } 4 \mathrm{mg} \text { or } 40 \mathrm{mg} \\
\text { once daily for } 28 \text { days. }\end{array}$ & $\begin{array}{l}\text { Did not improve } \\
\text { LVESV. }\end{array}$ & $\begin{array}{l}\text { By binding to } \\
\text { cardiolipin, } \\
\text { decreases ROS } \\
\text { production. }\end{array}$ & [252] \\
\hline Coenzyme $\mathrm{Q}_{10}$ & $\begin{array}{l}\text { Moderate to severe } \\
\text { HFrEF, } n=420 \text {. }\end{array}$ & $\begin{array}{l}\text { p.o., } 100 \mathrm{mg} 3 \text { times } \\
\text { daily, } 2 \text { years. }\end{array}$ & $\begin{array}{c}\text { Significantly } \\
\text { improved NYHA } \\
\text { class, CV events } \\
\downarrow \text { by } 50 \% .\end{array}$ & $\begin{array}{l}\text { Q10 is involved in } \\
\text { eNOS regulation }\end{array}$ & [243] \\
\hline
\end{tabular}

\subsection{Chemicals Increasing cGMP-PKG Signaling}

Constantijn Franssen, with co-authors, reviewed studies conducted before the year 2014 regarding medications that increased cGMP-PKG signaling [253]. The medicines 
reviewed were nitroxyl (HNO), enalapril, LCZ696 and sGC activators (e.g., cinaciguat, riociguat, vericiguat). HNO was shown to increase cGMP and to suppress NOX, resulting in an anti-hypertrophic effect in rat cardiomyocytes [254] and HFrEF patients [255], but clinical studies of the HNO effect in HFpEF were absent. LCZ696 was discussed in the chapter, "Renin-angiotensin system inhibitors". Cinaciguat did not show any effect on cardiac index [256]. Riociguat improved symptoms and NT-proBNP levels [257]. Vericiguat was evaluated in a Phase II trial study in HFrEF and HFpEF [258].

Knowledge about medications that increase cGMP-PKG signaling has grown in the last decade. Sodium-glucose cotransporter 2 inhibitor (SLGT2), soluble guanylate cyclase (sGC) activators, PDE inhibitors, NO donors, and the vasodilator hydralazine were investigated.

Empagliflozin (sodium-glucose cotransporter 2 inhibitor) and sGC activator were suggested to have antioxidant and anti-inflammatory features in the myocardium of HF rats and HFpEF patients [259]. The results revealed that empagliflozin reduced cardiovascular mortality, all-cause mortality, and the number of hospitalizations for HFrEF. Moreover, both empagliflozin and sGC activator improved cardiomyocyte function by enhancing the phosphorylation of titin and other myofilament proteins, presumably due to improved signaling pathways, such as the nitric oxide (NO)/soluble guanylyl cyclase (sGC)/cGMP-dependent protein kinase (PKG) signaling pathway (NO-sGC-cGMP-PKG pathway) and the CaMKII-mediated hypertrophic pathway, PKC, ERK2, in addition to the PKA pathway [259] (Figure 5).

The PDE5 inhibitor sildenafil can inhibit guanosine $3^{\prime}, 5^{\prime}$-cyclic monophosphate (cGMP) breakdown, improve cardiac relaxation and LV remodeling [260]. The catalytic site of PDE5 generally degrades cGMP, and sildenafil potentiates the endogenous increase in cGMP by inhibiting its degradation [261]. Sildenfil reduced pulmonary vascular resistance and right heart pressure in patients with HFrEF, who had secondary pulmonary hypertension, and long-term treatment improved exercise tolerance, functional capacity, LV diastolic function and cardiac geometry [262-264]. In a large, long-term (24 weeks) trial of sildenafil (RELAX), PDE5 inhibitor did not improve LV diastolic function and did not reduce hypertrophy and pulmonary pressures. In this study, sildenafil did not increase plasma cGMP concentrations, therefore, exercise capacity and clinical status did not improve [265].

NO donors were also investigated for their capacity to improve heart function. Some of these donors, such as Angeli's salt [266] and Piloty's acid [267], appeared to be unstable. In turn, pure NO donors, such as the congener of Piloty's acid, CXL-1020 [255], and the pro-drug of CXL-1020, cimlanod (BMS-986231), were generated [268]. The HNO donor BMS-986231 in animal models improved myocardial contractility and relaxation without increasing heart rate or oxygen consumption [269]. One study was performed with HFrEF, in which patients received intravenous infusions (i.v.) of BMS-986231 at various doses, and information about the safety and tolerability of medicine was provided [270]. However, the poor solubility of BMS-986231 limited its clinical use as an i.v. agent, and its oral bioavailability is still being investigated [268].

Major studies were performed with the protonated form of NO-nitroxyl (HNO). The action of $\mathrm{HNO}$ is preserved during oxidative stress because $\mathrm{HNO}$ does not react with superoxides [271], and undergoes moderate oxidative reactions through the formation of hydroxyl radicals [272]. HNO inhibits mitochondrial respiration by inhibiting complexes I and II, most likely by modifying specific cysteine residues in ETC proteins [273]. HNO increased cGMP levels and had NADPH oxidase (NOX2) inhibitory and antihypertrophic effects in rat cardiomyocytes [255]. HNO improved myocardial function due to direct positive lusitropic and inotropic effects, independent of cyclic adenosine monophosphate (cAMP), and due to combined venous and arterial dilation [274-278]. In addition, HNO modifies sarcomeric proteins to increase their $\mathrm{Ca}^{2+}$ sensitivity resulting in systolic force generation [270]. HNO also causes vasodilatation through endothelial soluble guanylate cyclase [266,279]. A recent study showed that HNO reduced left and right ventricle filling pressure and systemic vascular resistance in both animal and CHF patient models [255]. It was concluded that nitroxyl was well tolerated, reduced diastolic filling pressure and 
systemic vascular resistance, and raised cardiac output and stroke volume with unaltered heart rate [255]. Taken together, the novel cardio-protective properties of HNO show the therapeutic potential of HNO donors, particularly in situations where NO signaling is impaired (in HFpEF), but more detailed studies are required.

The vasodilator hydralazine has a beneficial effect on the balance between $\mathrm{NO}$ and $\mathrm{O}_{2}$, which is disturbed in patients with HF [280]. Clinical treatment with nitrates resulted in eventual tolerance to its vascular and hemodynamic effects, mainly due to endothelial dysfunction [281]. However, in combination with hydralazine, nitrate tolerance was avoided due to hydralazine inhibition on nitroglycerin-induced vascular $\mathrm{O}_{2}$, and peroxynitrite $\left(\mathrm{ONOO}^{-}\right)$formation in vitro [282] and in vivo [283]. Thus, the antioxidant effect of hydralazine and the prevention of the development of its tolerance in response to isosorbide dinitrate (ISDN) [284] may at least partially explain why this combination improves morbidity and mortality in patients with chronic congestive HF [285]. The African-American Heart Failure (A-HeFT) trial demonstrated that ISDN and hydralazine combination has a large effect on survival in patients with HFrEF [286].

Recently, new classes of drugs that increase cGMP production by targeting guanylate cyclase at the NO receptor (sGC) have been discovered. These were designed in order to generate cGMO independently of $\mathrm{NO}$ and to target signaling cascades in the cardiovascular system [287]. Enzymes with a unique mode of action activate the oxidized, heme-free form of sGC, which does not react with NO. The oxidation or absence of the heme moiety increases the effect of cinaciguat on the sGC, causing a significant cGMP increase [288]. These compounds are called sGC stimulators and sGC activators. They differ in that sGC stimulators are targeted to bind to the regulatory domain and trigger cGMP production by binding the heme-containing non-oxidized form of the sGC regulatory domain [289].

In recent years, the soluble stimulant sGC vericiguate has attracted the attention of the medical community following reports of reduced clinical outcomes in patients with chronic heart failure. The NO-sGC-cGMP pathway is mediated by a different mechanism that complements current drug therapy for cardiovascular disease. cGMP deficiency is a characteristic trait of both HFrEF and HFpEF [258]. Vericiguate acts synergistically with endogenous NO [285,290], which is considered a nitroconstrictor that produces cGMP at low levels of NO (Figure 5). By increasing cGMP, vericiguate has also been shown to promote vascular relaxation and improve vascular tone regulation and myocardial dysfunction [285,291-293]. This would also attenuate left ventricular remodeling by inducing PKG-induced phosphorylation of titin after activation of PKG by cGMP [292] (Figure 5). sGC activators are well discussed by Chien Y.T. et all [294]. Vericiguat is currently in phase 3 clinical trials for HFrEF (BAY 1021189) and praliciguat is now in phase 2, in HFpEF (IW-1973, IWP-121) [294]. Drugs that alter cardiomyocyte homeostasis by increasing cGMP-PKG signaling in HF patients are summarized in Table 4.

Table 4. Medicines affecting human cardiomyocytes by increasing cGMP-PKG signaling in HF patients. (LV-left ventricle, LA-left atrium).

\begin{tabular}{|c|c|c|c|c|c|}
\hline Medicine & Patients & $\begin{array}{c}\text { Appl., Dose and } \\
\text { Duration }\end{array}$ & Results & $\begin{array}{c}\text { Pathophysiological } \\
\text { Mechanism }\end{array}$ & Reference \\
\hline Empagliflozin & $\begin{array}{l}\text { HFpEF II-IV class } \\
(\mathrm{EF}>40 \%), n=2997 \\
\text { placebo } n=2991\end{array}$ & $\begin{array}{l}10 \mathrm{mg} \text { once daily or } \\
\text { placebo } 36 \text { months }\end{array}$ & $\begin{array}{c}\text { Reduced } \\
\text { cardiovascular } \\
\text { death and } \\
\text { hospitalization }\end{array}$ & $\begin{array}{l}\text { SLGT2 inhibitor } \\
\text { and sGC activator }\end{array}$ & [295] \\
\hline Sildenafil & $\begin{array}{l}\text { Stable outpatient } \\
\text { individuals with } \\
\text { HFpEF, } n=160 .\end{array}$ & 24 weeks & $\begin{array}{l}\text { Did not improve } \\
\text { exercise capacity } \\
\text { and clinical status. }\end{array}$ & $\begin{array}{l}\text { Inhibits cGMP } \\
\text { breakdown }\end{array}$ & [265] \\
\hline
\end{tabular}


Table 4. Cont.

\begin{tabular}{|c|c|c|c|c|c|}
\hline Medicine & Patients & $\begin{array}{l}\text { Appl., Dose and } \\
\text { Duration }\end{array}$ & Results & $\begin{array}{c}\text { Pathophysiological } \\
\text { Mechanism }\end{array}$ & Reference \\
\hline Nitroxyl & $\mathrm{HFpEF}, n=65$ & 23 months & $\begin{array}{l}\text { HNO increased cGMP } \\
\text { concentrations and } \\
\text { had NOX inhibitory } \\
\text { and antihypertrophic } \\
\text { effects in rat } \\
\text { cardiomyocytes. }\end{array}$ & NO donor. & [255] \\
\hline Cymlanod & $\mathrm{HFrEF}, n=45$ & $\begin{array}{l}5 \text { h i.v infusion or } \\
\text { placebo }\end{array}$ & $\begin{array}{l}\text { Slightly reduced LV } \\
\text { and LA volumes }\end{array}$ & NO donor & [296] \\
\hline Hydralazine & $\begin{array}{c}\text { HFrEF, NYHA class } \\
\text { III-IV (EF } \leq 35 \% \text { or } \\
<45 \% \text { with LVIDd } \\
>2.9 \mathrm{~cm} / \mathrm{m}), n=1050 .\end{array}$ & 18 months & Improved survival. & $\begin{array}{c}\text { ROS scavenger; } \\
\text { Inhibitor of } \\
\mathrm{O}_{2}^{-} \text {generation; } \\
\text { normalizes } \\
\text { endogenous rates } \\
\text { of vascular } \\
\mathrm{O}_{2}{ }^{-} \text {production } \\
\text { [122]. }\end{array}$ & [286] \\
\hline Cinaciguat & HFrEF. $n=62$ & 1 year & $\begin{array}{l}\text { Did not significantly } \\
\text { improve dyspnea or } \\
\text { cardiac index. }\end{array}$ & $\begin{array}{l}\text { Increases cGMP } \\
\text { production by } \\
\text { targeting } \\
\text { guanylate cyclase } \\
\text { at the NO receptor } \\
\text { (sGC). }\end{array}$ & [256] \\
\hline \multirow[t]{4}{*}{ Vericiguat } & $\begin{array}{c}\text { HFrEF, (LVEF }<45 \% \text {, } \\
\text { history of } \\
\text { decompensation } \\
\text { within the last four } \\
\text { weeks), } n=456\end{array}$ & $\begin{array}{l}1.25 \mathrm{mg}, 2.5 \mathrm{mg}, 5 \mathrm{mg} \text {, } \\
\text { or } 10 \mathrm{mg} \text { for } 12 \text { weeks }\end{array}$ & $\begin{array}{l}\text { Was well-tolerated and } \\
\text { higher doses were } \\
\text { associated with a } \\
\text { greater reduction in } \\
\text { NT-pro BNP level. } \\
\text { Appeared to be }\end{array}$ & \multirow{4}{*}{$\begin{array}{l}\text { Triggers cGMP } \\
\text { production by } \\
\text { binding the } \\
\text { heme-containing } \\
\text { non-oxidized form } \\
\text { of sGC regulatory } \\
\text { domain. }\end{array}$} & [290] \\
\hline & $\begin{array}{l}\text { HFpEF ( LVEF > 45\% } \\
\text { and a history of } \\
\text { decompensation } \\
\text { within the last } \\
\text { four weeks), } n=477\end{array}$ & $\begin{array}{l}\text { from } 1.25 \mathrm{mg} \text { to } 10 \mathrm{mg} \\
\text { once daily for } \\
12 \text { weeks }\end{array}$ & $\begin{array}{l}\text { well-tolerated and } \\
\text { improved patients } \\
\text { with HFpEF quality of } \\
\text { life; however, had no } \\
\text { significant impact on } \\
\text { NT-proBNP level. }\end{array}$ & & [297] \\
\hline & $\begin{array}{c}\text { HFpEF (LVEF > 45\%), } \\
n=789 \\
\text { HFpEF (NYHA II to }\end{array}$ & $15 \mathrm{mg}$ or $10 \mathrm{mg}$ daily & $\begin{array}{l}\text { No significant changes } \\
\text { were observed. }\end{array}$ & & [298] \\
\hline & $\begin{array}{l}\text { IV) with an } \\
\text { LVEF }<45 \% \text {, history of } \\
\text { decompensation over } \\
\text { the last six months, } \\
\text { elevated NT-proBNP } \\
\text { or BNP), } n=5050\end{array}$ & $\begin{array}{l}10 \mathrm{mg} \text { once daily } \\
\text { for } 10.8 \text { months }\end{array}$ & $\begin{array}{l}\text { Hospitalization for } \\
\text { heart failure and death } \\
\text { from cardiovascular } \\
\text { causes were reduced } \\
\text { compared to placebo. }\end{array}$ & & [299] \\
\hline
\end{tabular}

To conclude, AMPK activators are suggested to improve heart function in animal models, and, with further research, have potential to be beneficial for patients with chronic HF. The AT1R and neprilysin inhibitor valsartan/sacubitril has been investigated in most detail of all Ang II inhibitors and was included in guidelines for HFrEF treatment. Kaempherol displayed cardioprotective effects in cell culture [203,204]; however, further clinical studies are needed in order to assess its suitability and beneficial effects for patients. The utility of antioxidants, mitochondrial-function-affecting drugs and MAO inhibitors have been poorly studied to date. Both the SLGT2 inhibitor, sGC activator empagliflozin and vericiguat produced gratifying treatment results in patients with $\mathrm{HFpEF}$. 


\section{Conclusions}

Mitochondrial damage, inflammation and enzyme-oxidants (NOX, XOR, NOS), as well as decreased activity of enzyme-antioxidants (GPX and PRX), can be assumed to be the main triggers for excess amounts of ROS in cardiomyocytes. AT1R is involved in NOX activation in both cardiomyocytes and fibroblasts. Enzyme-oxidants act through MAPK and NO synthesis inhibition pathways, leading to cardiomyocyte hypertrophy and interstitial fibrosis. Pro-inflammatory cytokines trigger ROS overproduction, leading to mitochondrial structural damage due to membrane protein, ion channel protein and protein acetylation in HFrEF mitochondria. Therefore, damaged mitochondria are suggested to be the main ROS source in HFrEF, while NO decrease, NO-sGC-cGMP signaling inhibition by ROS and enzymes iNOS, eNOS, PDE are understood to be the most important factors in HFpEF development.

The pathways involving both AMPK and MAPK protein kinases, AT1R and cGMPPKG, are considered as treatment targets for halting chronic HF development. Therefore, some compound groups for oxidative stress-induced myocardial damage/remodeling reduction in HF development include: (1) activators of AMPK, (2) RAAS inhibitors, (3) inhibitors of ROS producing enzymes, (4) antioxidants, (5) MAO inhibitors, (6) medications that improve mitochondrial function, and (7) substances that increase cGMP-PKG signaling.

Achievements in reducing ROS-induced harmful pathways in chronic HF can be summarized as follows: AMPK activators are suggested to improve heart function in animal models, therefore, exploratory studies with patients afflicted with chronic HF could prove to be of great value. AT1R and the neprilysin inhibitor valsartan/sacubitril have been investigated in the most detail of all. Ang II inhibitors have yielded favorable results and been included in HFrEF treatment guidelines. Kaempherol displayed cardioprotective effects in animal models, but clinical studies are still needed to verify the suitability and treatment benefits in humans. XOR inhibitors and management of the NOS activity in chronic HF patient treatment are still in research stages. Further studies that investigate the benefits of NOX inhibition or Mito-Q effect in CHF patients are needed. The usefulness of antioxidants, mitochondrial-function-affecting drugs and MAO inhibitors are still poorly studied and understood. Both the SLGT2 inhibitor and the SGC activator empagliflozin and vericiguat displayed gratifying results in HFpEF treatment; however, their effects still require to be confirmed in randomized studies.

\section{Perspectives}

ROS were shown to be involved in both HFrEF and HFpEF pathogenesis through different pathways. Although treatment with unselective antioxidative treatment failed to demonstrate better outcomes in HFrEF and HFpEF patients, oxidative stress remains the focus of intensive research. It appears that selective antioxidant treatment ought to give more favorable results. Treatment regarding mitochondrial function improvement and cGMP-PKG signaling appear to need deeper investigation for both CHF patient groups. In $\mathrm{HFrEF}$, patient usage of AMPK activators should be evaluated.

Author Contributions: Conceptualization, A.M.; writing-original draft preparation, A.M., L.S., L.V., G.M., J.G.; writing-review and editing, L.S., L.V., G.M., J.G.; visualization, L.S., J.G. All authors contributed equally. All authors have read and agreed to the published version of the manuscript.

Funding: This research received no external funding.

Informed Consent Statement: Not applicable.

Data Availability Statement: Not applicable.

Conflicts of Interest: The authors declare no conflict of interest. 


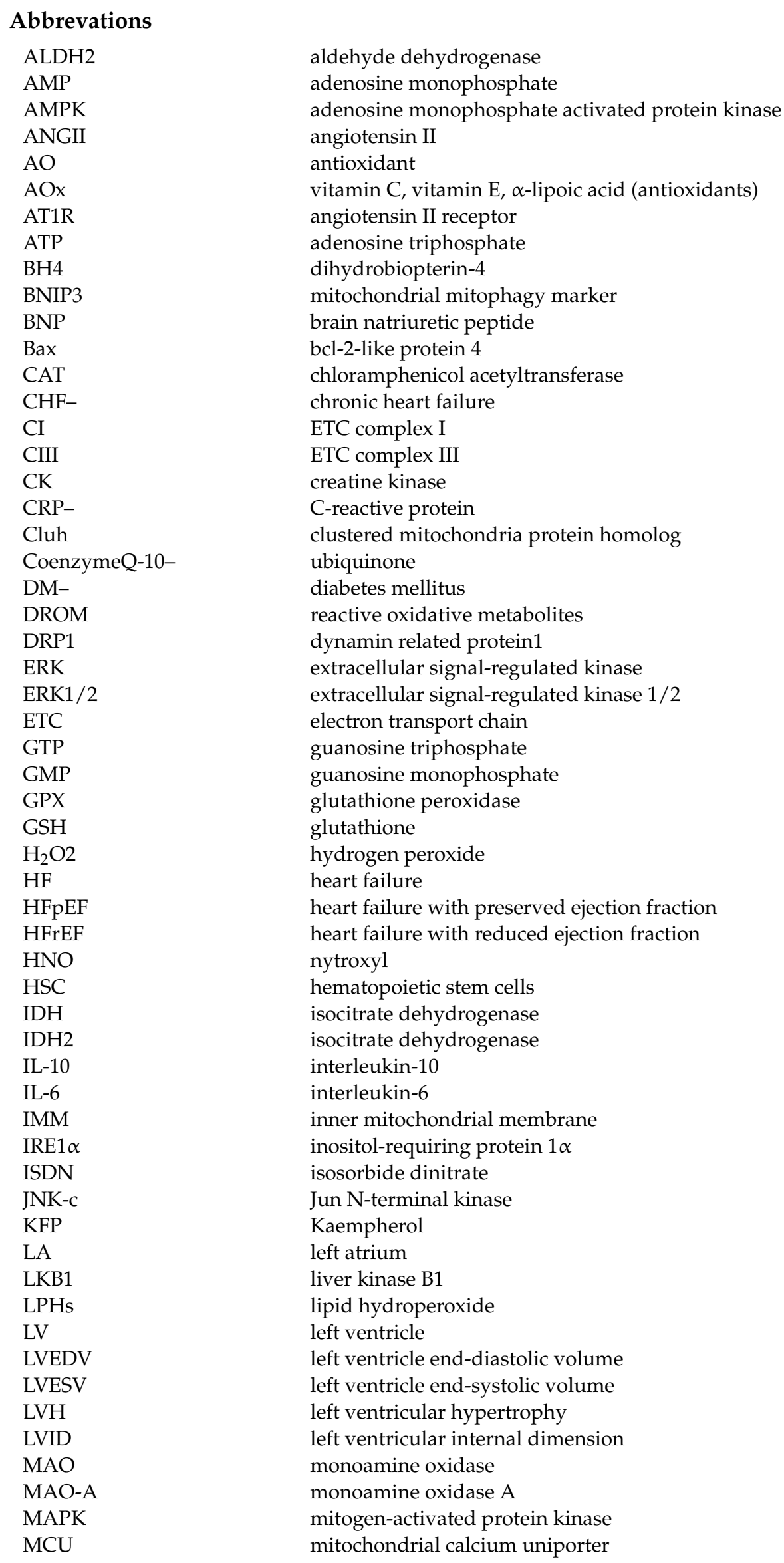




\begin{tabular}{|c|c|}
\hline MMPs & matrix metalloproteinase \\
\hline NAPDH- & nicotinamide adenine dinucleotide phosphate \\
\hline NFKB & nuclear factor kappa-B \\
\hline NHE-1 & $\mathrm{Na}^{+} / \mathrm{Ca}^{2+}$ exchanger \\
\hline NO & nitric oxide \\
\hline NO-2 & plasma nitrite \\
\hline NOS & nitric oxide synthase \\
\hline NOX & nicotinamide adenine dinucleotide phosphate oxidase \\
\hline NP & natriuretic peptide \\
\hline NT-proBNP & N-terminal pro b-type natriuretic peptide \\
\hline NYHA- & New York Heart Association \\
\hline OMM & outer mitochondrial membrane \\
\hline $\mathrm{ONOO}^{-}$ & peroxynitrite \\
\hline OPA1 & optic atrophy 1 \\
\hline P38 & a focal point of interactions of the serine/threonine kinases \\
\hline PDE & phosphodiesterases \\
\hline PKA & protein kinase A \\
\hline PKB & protein kinase B \\
\hline PKC & protein kinase $C$ \\
\hline PKG & protein kinase $G$ \\
\hline PKS & protein kinase $S$ \\
\hline PRR & pathogen recognition receptor \\
\hline PRX & peroxiredoxin \\
\hline RAAS & renin-angiotensin-aldosterone system \\
\hline ROS & reactive oxygen species \\
\hline Rac-1 & GTP-binding protein \\
\hline SGLT2 & sodium-glucose cotransporter \\
\hline SIRT & NAD+ dependent class III histone deacetylases \\
\hline SOD & superoxide dismutase \\
\hline TGF $\beta$ & tumor growth factor $\beta$ \\
\hline TNF- $\alpha$ & tumor necrosis factor- $\alpha$ \\
\hline TPP & triphenylphosphonium cation \\
\hline TXNIP & thioredoxin-interacting protein \\
\hline UCP2 & uncoupling protein 2 \\
\hline VDAC1 & voltage-dependent anion channel 1 \\
\hline XBP1s & X-box-binding protein 1 \\
\hline $\mathrm{XO}$ & xanthine oxidase \\
\hline XOR & xanthine oxidoreductase \\
\hline cAMP & cyclic adenosine monophosphate \\
\hline cGMP & cyclic guanosine monophosphate \\
\hline eNOS & endothelial nitric oxide synthase \\
\hline hs-CRP & high-sensitivity C-reactive protein \\
\hline iNOS & inducible nitric oxide synthase \\
\hline nNOS & neuronal nitric oxide synthase \\
\hline pGC & particulate guanylyl cyclase \\
\hline sGC & soluble guanylate cyclase \\
\hline$\beta-O X$ & beta-oxidation \\
\hline
\end{tabular}

\section{References}

1. Holland, D.; Kumbhani, D.J.; Ahmed, S.H.; Marwick, T.H. Effects of Treatment on Exercise Tolerance, Cardiac Function, and Mortality in Heart Failure with Preserved Ejection Fraction: A Meta-Analysis. J. Am. Coll. Cardiol. 2011, 57, 1676-1686. [CrossRef] [PubMed]

2. Henning, R.J. Diagnosis and treatment of heart failure with preserved left ventricular ejection fraction. World J. Cardiol. 2020, 12, 7-25. [CrossRef]

3. Shah, A.M.; Mann, D. In search of new therapeutic targets and strategies for heart failure: Recent advances in basic science. Lancet 2011, 378, 704-712. [CrossRef]

4. Shah, S.; Kitzman, D.W.; Borlaug, B.; Van Heerebeek, L.; Zile, M.; Kass, D.A.; Paulus, W.J. Phenotype-Specific Treatment of Heart Failure with Preserved Ejection Fraction. Circulation 2016, 134, 73-90. [CrossRef] [PubMed] 
5. Ponikowski, P.; Voors, A.A.; Anker, S.D.; Bueno, H.; Cleland, J.G.F.; Coats, A.J.S. 2016 ESC Guidelines for the diagnosis and treatment of acute and chronic heart failure: The Task Force for the diagnosis and treatment of acute and chronic heart failure of the European Society of Cardiology (ESC)Developed with the special contribution of. Eur. Heart J. 2016, 37, 2129-2200. [CrossRef]

6. Bertero, E.; Maack, C. Calcium Signaling and Reactive Oxygen Species in Mitochondria. Circ. Res. 2018, 122, 1460-1478. [CrossRef]

7. Sorescu, D.; Griendling, K.; Sorescu, D.; Griendling, K. Reactive Oxygen Species, Mitochondria, and NAD(P)H Oxidases in the Development and Progression of Heart Failure. Congest. Heart Fail. 2002, 8, 132-140. [CrossRef]

8. Collin, F. Chemical Basis of Reactive Oxygen Species Reactivity and Involvement in Neurodegenerative Diseases. Int. J. Mol. Sci. 2019, 20, 2407. [CrossRef]

9. Panth, N.; Paudel, K.R.; Parajuli, K. Reactive Oxygen Species: A Key Hallmark of Cardiovascular Disease. Adv. Med. 2016, 2016, 9152732. [CrossRef]

10. Wardman, P.; Candeias, L.P. Fenton chemistry: An introduction. Radiat. Res. 1996, 145, 523-531. [CrossRef]

11. Münzel, T.; Gori, T.; Keaney, J.; Maack, C.; Daiber, A. Pathophysiological role of oxidative stress in systolic and diastolic heart failure and its therapeutic implications. Eur. Heart J. 2015, 36, 2555-2564. [CrossRef] [PubMed]

12. Ferdinandy, P.; Danial, H.; Ambrus, I.; Rothery, R.; Schulz, R. Peroxynitrite Is a Major Contributor to Cytokine-Induced Myocardial Contractile Failure. Circ. Res. 2000, 87, 241-247. [CrossRef] [PubMed]

13. Hansen, J.M.; Go, Y.-M.; Jones, D.P. Nuclear and mitochondrial compartmentation of oxidative stress and redox signaling. Annu. Rev. Pharmacol. Toxicol. 2006, 46, 215-234. [CrossRef] [PubMed]

14. Glasauer, A.; Chandel, N.S. Targeting antioxidants for cancer therapy. Biochem. Pharmacol. 2014, 92, 90-101. [CrossRef] [PubMed]

15. Santos, C.X.; Raza, S.; Shah, A.M. Redox signaling in the cardiomyocyte: From physiology to failure. Int. J. Biochem. Cell Biol. 2016, 74, 145-151. [CrossRef]

16. Zurlo, G.; Guo, J.; Takada, M.; Wei, W.; Zhang, Q. New Insights into Protein Hydroxylation and Its Important Role in Human Diseases. Biochim. Biophys. Acta 2016, 1866, 208-220. [CrossRef]

17. Stomberski, C.; Hess, D.T.; Stamler, J.S. Protein S-Nitrosylation: Determinants of Specificity and Enzymatic Regulation of S-Nitrosothiol-Based Signaling. Antioxid. Redox Signal. 2019, 30, 1331-1351. [CrossRef]

18. Turrens, J.F. Mitochondrial formation of reactive oxygen species. J. Physiol. 2003, 552, 335-344. [CrossRef]

19. Burgoyne, J.R.; Mongue-Din, H.; Eaton, P.; Shah, A.M. Redox signaling in cardiac physiology and pathology. Circ. Res. 2012, 111, 1091-1106. [CrossRef]

20. Deponte, M. Glutathione catalysis and the reaction mechanisms of glutathione-dependent enzymes. Biochim. Biophys. Acta Gen. Subj. 2013, 1830, 3217-3266. [CrossRef]

21. Dhalla, N.S.; Temsah, R.M.; Netticadan, T. Role of oxidative stress in cardiovascular diseases. J. Hypertens. 2000, 18, 655-673. [CrossRef] [PubMed]

22. Kotiadis, V.; Duchen, M.R.; Osellame, L.D. Mitochondrial quality control and communications with the nucleus are important in maintaining mitochondrial function and cell health. Biochim. Biophys. Acta Gen. Subj. 2013, 1840, 1254-1265. [CrossRef] [PubMed]

23. Takimoto, E.; Kass, D.A. Role of Oxidative Stress in Cardiac Hypertrophy and Remodeling. Hypertension 2007, 49, 241-248. [CrossRef] [PubMed]

24. Sawyer, D.B.; Siwik, D.A.; Xiao, L.; Pimentel, D.R.; Singh, K.; Colucci, W.S. Role of Oxidative Stress in Myocardial Hypertrophy and Failure. J. Mol. Cell. Cardiol. 2002, 34, 379-388. [CrossRef]

25. Christiansen, L.B.; Dela, F.; Koch, J.; Hansen, C.N.; Leifsson, P.S.; Yokota, T. Impaired cardiac mitochondrial oxidative phosphorylation and enhanced mitochondrial oxidative stress in feline hypertrophic cardiomyopathy. Am. J. Physiol. Circ. Physiol. 2015, 308, H1237-H1247. [CrossRef]

26. Weissman, D.; Maack, C. Redox signaling in heart failure and therapeutic implications. Free Radic. Biol. Med. 2021, 171, 345-364. [CrossRef]

27. Burgoyne, J.R.; Madhani, M.; Cuello, F.; Charles, R.L.; Brennan, J.P.; Schröder, E. Cysteine redox sensor in PKGIa enables oxidant-induced activation. Science 2007, 317, 1393-1397. [CrossRef]

28. Kuster, G.M.; Siwik, D.A.; Pimentel, D.R.; Colucci, W.S. Role of Reversible, Thioredoxin-Sensitive Oxidative Protein Modifications in Cardiac Myocytes. Antioxid. Redox Signal. 2006, 8, 2153-2159. [CrossRef]

29. Erickson, J.R.; Joiner, M.-L.A.; Guan, X.; Kutschke, W.; Yang, J.; Oddis, C.V.; Bartlett, R.K.; Lowe, J.S.; O’Donnell, S.E.; Aykin-Burns, N.; et al. A Dynamic Pathway for Calcium-Independent Activation of CaMKII by Methionine Oxidation. Cell 2008, 133, 462-474. [CrossRef]

30. Brennan, J.P.; Bardswell, S.C.; Burgoyne, J.R.; Fuller, W.; Schröder, E.; Wait, R. Oxidant-induced activation of type I protein kinase A is mediated by RI subunit interprotein disulfide bond formation. J. Biol. Chem. 2006, 281, 21827-21836. [CrossRef]

31. Ago, T.; Liu, T.; Zhai, P.; Chen, W.; Li, H.; Molkentin, J.; Vatner, S.F.; Sadoshima, J. A Redox-Dependent Pathway for Regulating Class II HDACs and Cardiac Hypertrophy. Cell 2008, 133, 978-993. [CrossRef] [PubMed]

32. Sood, H.S.; Cox, M.J.; Tyagi, S.C. Generation of Nitrotyrosine Precedes Activation of Metalloproteinase in Myocardium of Hyperhomocysteinemic Rats. Antioxid. Redox Signal. 2002, 4, 799-804. [CrossRef] [PubMed]

33. Yasukawa, T.; Tokunaga, E.; Ota, H.; Sugita, H.; Martyn, J.A.J.; Kaneki, M. S-Nitrosylation-dependent Inactivation of Akt/Protein Kinase B in Insulin Resistance. J. Biol. Chem. 2005, 280, 7511-7518. [CrossRef]

34. Kehat, I.; Molkentin, J.D. Extracellular signal-regulated kinase 1/2 (ERK1/2) signaling in cardiac hypertrophy. Ann. N. Y. Acad. Sci. 2010, 1188, 96-102. [CrossRef] [PubMed] 
35. Meijles, D.N.; Cull, J.J.; Markou, T.; Cooper, S.T.; Haines, Z.H.; Fuller, S.J.; O'Gara, P.; Sheppard, M.N.; Harding, S.; Sugden, P.H.; et al. Redox Regulation of Cardiac ASK1 (Apoptosis Signal-Regulating Kinase 1) Controls p38-MAPK (Mitogen-Activated Protein Kinase) and Orchestrates Cardiac Remodeling to Hypertension. Hypertension 2020, 76, 1208-1218. [CrossRef] [PubMed]

36. Newton, A.C.; Antal, C.E.; Steinberg, S.F. Protein kinase C mechanisms that contribute to cardiac remodelling. Clin. Sci. 2016, 130, 1499-1510. [CrossRef]

37. Gao, G.; Dudley, S.C. Redox regulation, NF-kappaB, and atrial fibrillation. Antioxid. Redox Signal 2009, 11, 2265-2277. [CrossRef]

38. Sasaki, H.; Galang, N.; Maulik, N. Redox regulation of NF-kappaB and AP-1 in ischemic reperfused heart. Antioxid. Redox Signal 1999, 1, 317-324. [CrossRef]

39. Ho, E.; Karimi Galougahi, K.; Liu, C.-C.; Bhindi, R.; Figtree, G.A. Biological markers of oxidative stress: Applications to cardiovascular research and practice. Redox Biol. 2013, 1, 483-491. [CrossRef]

40. Nakamura, K.; Fushimi, K.; Kouchi, H.; Mihara, K.; Miyazaki, M.; Ohe, T.; Namba, M. Inhibitory Effects of Antioxidants on Neonatal Rat Cardiac Myocyte Hypertrophy Induced by Tumor Necrosis Factor- $\alpha$ and Angiotensin II. Circulation 1998, 98, 794-799. [CrossRef]

41. Yokoyama, T.; Nakano, M.; Bednarczyk, J.L.; McIntyre, B.W.; Entman, M.; Mann, U.L. Tumor Necrosis Factor- $\alpha$ Provokes a Hypertrophic Growth Response in Adult Cardiac Myocytes. Circulation 1997, 95, 1247-1252. [CrossRef]

42. Yamazaki, T.; Komuro, I.; Zou, Y.; Kudoh, S.; Shiojima, I.; Hiroi, Y. Norepinephrine induces the raf-1 kinase/mitogen-activated protein kinase cascade through both alpha 1- and beta-adrenoceptors. Circulation 1997, 95, 1260-1268. [CrossRef] [PubMed]

43. Balaban, R.S.; Nemoto, S.; Finkel, T. Mitochondria, oxidants, and aging. Cell 2005, 120, 483-495. [CrossRef] [PubMed]

44. Wijnker, P.J.; Sequeira, V.; Kuster, D.W.; Van Der Velden, J. Hypertrophic Cardiomyopathy: A Vicious Cycle Triggered by Sarcomere Mutations and Secondary Disease Hits. Antioxid. Redox Signal. 2019, 31, 318-358. [CrossRef]

45. Del Rio, D.; Stewart, A.J.; Pellegrini, N. A review of recent studies on malondialdehyde as toxic molecule and biological marker of oxidative stress. Nutr. Metab. Cardiovasc. Dis. 2005, 15, 316-328. [CrossRef] [PubMed]

46. Horacio, E.C.; Cingolani, H.E.; Perez, N.G.; Aiello, E.A.; Ennis, I.L.; Garciarena, C.D.; Villa-Abrille, M.C.; Dulce, R.A.; Caldiz, C.I.; Yeves, A.M.; et al. Early signals after stretch leading to cardiac hypertrophy. Key role of NHE-1. Front. Biosci. 2008, 13, 7096-7114. [CrossRef]

47. Palomeque, J.; Rueda, O.V.; Sapia, L.; Valverde, C.A.; Salas, M.; Petroff, M.V.; Mattiazzi, A. Angiotensin II-Induced Oxidative Stress Resets the $\mathrm{Ca}^{2+}$ Dependence of $\mathrm{Ca}^{2+}$-Calmodulin Protein Kinase II and Promotes a Death Pathway Conserved Across Different Species. Circ. Res. 2009, 105, 1204-1212. [CrossRef]

48. Zhao, R.Z.; Jiang, S.; Zhang, L.; Yu, Z.-B. Mitochondrial electron transport chain, ROS generation and uncoupling (Review). Int. J. Mol. Med. 2019, 44, 3-15. [CrossRef]

49. Marck, P.; Pessoa, M.; Xu, Y.; Kutz, L.; Collins, D.; Yan, Y.; King, C.; Wang, X.; Duan, Q.; Cai, L.; et al. Cardiac Oxidative Signaling and Physiological Hypertrophy in the Na/K-ATPase $\alpha 1^{\mathrm{s} / \mathrm{s}} \alpha 2^{\mathrm{s} / \mathrm{s}}$ Mouse Model of High Affinity for Cardiotonic Steroids. Int. J. Mol. Sci. 2021, 22, 3462. [CrossRef]

50. Pieske, B.; Maier, L.S.; PiacentinoIII, V.; Weisser, J.; Hasenfuss, G.; Houser, S. Rate Dependence of $\left[\mathrm{Na}^{+}\right]$i and Contractility in Nonfailing and Failing Human Myocardium. Circulation 2002, 106, 447-453. [CrossRef]

51. Liu, Y.; Wang, H.; Wang, J.; Wei, B.; Zhang, X.; Zhang, M.; Cao, D.; Dai, J.; Wang, Z.; Nyirimigabo, E.; et al. A positive feedback regulation of Heme oxygenase 1 by CELF1 in cardiac myoblast cells. Biochim. Biophys. Acta Gene Regul. Mech. 2019, 1862, 209-218. [CrossRef]

52. AlHayaza, R.; Haque, E.; Karbasiafshar, C.; Sellke, F.W.; Abid, M.R. The Relationship Between Reactive Oxygen Species and Endothelial Cell Metabolism. Front. Chem. 2020, 8, 592688. [CrossRef] [PubMed]

53. Incalza, M.A.; D'Oria, R.; Natalicchio, A.; Perrini, S.; Laviola, L.; Giorgino, F. Oxidative stress and reactive oxygen species in endothelial dysfunction associated with cardiovascular and metabolic diseases. Vasc. Pharmacol. 2018, 100, 1-19. [CrossRef]

54. Cimmino, G.; Cirillo, P.; Ragni, M.; Conte, S.; Uccello, G.; Golino, P. Reactive oxygen species induce a procoagulant state in endothelial cells by inhibiting tissue factor pathway inhibitor. J. Thromb. Thrombolysis 2015, 40, 186-192. [CrossRef] [PubMed]

55. Zhang, M.; Perino, A.; Ghigo, A.; Hirsch, E.; Shah, A.M. NADPH Oxidases in Heart Failure: Poachers or Gamekeepers? Antioxid. Redox Signal 2013, 18, 1024. [CrossRef] [PubMed]

56. Ekelund, U.E.G.; Harrison, R.W.; Shokek, O.; Thakkar, R.N.; Tunin, R.S.; Senzaki, H.; Kass, D.A.; Marbaán, E.; Hare, J.M. Intravenous Allopurinol Decreases Myocardial Oxygen Consumption and Increases Mechanical Efficiency in Dogs with PacingInduced Heart Failure. Circ. Res. 1999, 85, 437-445. [CrossRef] [PubMed]

57. Jankovic, A.; Korac, A.; Buzadzic, B.; Stancic, A.; Otasevic, V.; Ferdinandy, P.; Daiber, A.; Korac, B. Targeting the NO/superoxide ratio in adipose tissue: Relevance to obesity and diabetes management. J. Cereb. Blood Flow Metab. 2016, 174, 1570-1590. [CrossRef] [PubMed]

58. Looi, Y.H.; Grieve, D.J.; Siva, A.; Walker, S.J.; Anilkumar, N.; Cave, A.C.; Marber, M.; Monaghan, M.J.; Shah, A.M. Involvement of Nox2 NADPH Oxidase in Adverse Cardiac Remodeling After Myocardial Infarction. Hypertension 2008, 51, 319-325. [CrossRef]

59. Lassègue, B.; San Martín, A.; Griendling, K.K. Biochemistry, Physiology, and Pathophysiology of NADPH Oxidases in the Cardiovascular System. Circ. Res. 2012, 110, 1364-1390. [CrossRef]

60. Prosser, B.L.; Ward, C.W.; Lederer, W.J. X-ROS Signaling: Rapid Mechano-Chemo Transduction in Heart. Science 2011, 333, 1440-1445. [CrossRef] 
61. Izu, L.T.; Kohl, P.; Boyden, P.A.; Miura, M.; Banyasz, T.; Chiamvimonvat, N. Mechano-Electric and Mechano-Chemo-Transduction in Cardiomyocytes. J. Physiol. 2020, 598, 1285. [CrossRef] [PubMed]

62. Murdoch, C.E.; Zhang, M.; Cave, A.C.; Shah, A.M. NADPH oxidase-dependent redox signalling in cardiac hypertrophy, remodelling and failure. Cardiovasc. Res. 2006, 71, 208-215. [CrossRef] [PubMed]

63. Takimoto, E.; Champion, H.C.; Li, M.; Ren, S.; Rodriguez, E.R.; Tavazzi, B.; Lazzarino, G.; Paolocci, N.; Gabrielson, K.L.; Wang, Y.; et al. Oxidant stress from nitric oxide synthase-3 uncoupling stimulates cardiac pathologic remodeling from chronic pressure load. J. Clin. Investig. 2005, 115, 1221-1231. [CrossRef] [PubMed]

64. Cheng, D.; Chen, L.; Tu, W.; Wang, H.; Wang, Q.; Meng, L. Protective effects of valsartan administration on doxorubicin-induced myocardial injury in rats and the role of oxidative stress and NOX2/NOX4 signaling. Mol. Med. Rep. 2020, 22, 4151-4162. [CrossRef]

65. McNally, J.S.; Davis, M.E.; Giddens, D.P.; Saha, A.; Hwang, J.; Dikalov, S.; Jo, H.; Harrison, D.G. Role of xanthine oxidoreductase and $\mathrm{NAD}(\mathrm{P}) \mathrm{H}$ oxidase in endothelial superoxide production in response to oscillatory shear stress. Am. J. Physiol. Circ. Physiol. 2003, 285, H2290-H2297. [CrossRef]

66. Nakagami, H.; Takemoto, M.; Liao, J.K. NADPH oxidase-derived superoxide anion mediates angiotensin II-induced cardiac hypertrophy. J. Mol. Cell. Cardiol. 2003, 35, 851-859. [CrossRef]

67. Higuchi, Y.; Otsu, K.; Nishida, K.; Hirotani, S.; Nakayama, H.; Yamaguchi, O. The Small GTP-binding Protein Rac1 Induces Cardiac Myocyte Hypertrophy through the Activation of Apoptosis Signal-regulating Kinase 1 and Nuclear Factor-kB*. J. Biol. Chem. 2003, 278, 20770-20777. [CrossRef]

68. Xiao, L.; Pimental, D.R.; Amin, J.K.; Singh, K.; Sawyer, D.B.; Colucci, W.S. MEK1/2-ERK1/2 mediates alpha1-adrenergic receptor-stimulated hypertrophy in adult rat ventricular myocytes. J. Mol. Cell Cardiol. 2001, 33, 779-787. [CrossRef]

69. Byrne, J.A.; Grieve, D.J.; Bendall, J.K.; Li, J.-M.; Gove, C.; Lambeth, J.D.; Cave, A.C.; Shah, A.M. Contrasting Roles of NADPH Oxidase Isoforms in Pressure-Overload Versus Angiotensin II-Induced Cardiac Hypertrophy. Circ. Res. 2003, 93, 802-805. [CrossRef]

70. Bendall, J.K.; Cave, A.C.; Heymes, C.; Gall, N.; Shah, A.M. Pivotal Role of a gp91 phox -Containing NADPH Oxidase in Angiotensin II-Induced Cardiac Hypertrophy in Mice. Circulation 2002, 105, 293-296. [CrossRef]

71. Grote, K.; Flach, I.; Luchtefeld, M.; Akin, E.; Holland, S.M.; Drexler, H.; Schieffer, B. Mechanical Stretch Enhances mRNA Expression and Proenzyme Release of Matrix Metalloproteinase-2 (MMP-2) via NAD(P)H Oxidase-Derived Reactive Oxygen Species. Circ. Res. 2003, 92, e80-e86. [CrossRef] [PubMed]

72. Sun, Y.; Zhang, J.; Lu, L.; Chen, S.S.; Quinn, M.T.; Weber, K.T. Aldosterone-induced inflammation in the rat heart: Role of oxidative stress. Am. J. Pathol. 2002, 161, 1773-1781. [CrossRef]

73. Luchtefeld, M.; Grote, K.; Grothusen, C.; Bley, S.; Bandlow, N.; Selle, T.; Strüber, M.; Haverich, A.; Bavendiek, U.; Drexler, H.; et al Angiotensin II induces MMP-2 in a p47phox-dependent manner. Biochem. Biophys. Res. Commun. 2005, 328, 183-188. [CrossRef]

74. Johar, S.; Cave, A.C.; Narayanapanicker, A.; Grieve, D.J.; Shah, A.M. Aldosterone mediates angiotensin II-induced interstitial cardiac fibrosis via a Nox2-containing NADPH oxidase. FASEB J. 2006, 20, 1546-1548. [CrossRef] [PubMed]

75. Colston, J.T.; De La Rosa, S.D.; Strader, J.R.; Anderson, M.A.; Freeman, G.L. $\mathrm{H}_{2} \mathrm{O}_{2}$ activates Nox4 through PLA2-dependent arachidonic acid production in adult cardiac fibroblasts. FEBS Lett. 2005, 579, 2533-2540. [CrossRef]

76. Cucoranu, I.; Clempus, R.; Dikalova, A.; Phelan, P.J.; Ariyan, S.; Dikalov, S. NAD(P)H oxidase 4 mediates transforming growth factor-beta1-induced differentiation of cardiac fibroblasts into myofibroblasts. Circ. Res. 2005, 97, 900-907. [CrossRef]

77. Harrison, R. Structure and function of xanthine oxidoreductase: Where are we now? Free Radic. Biol. Med. 2002, 33, 774-797. [CrossRef]

78. Harrison, R. Physiological Roles of Xanthine Oxidoreductase. Drug Metab. Rev. 2004, 36, 363-375. [CrossRef]

79. Gladden, J.D.; Zelickson, B.R.; Wei, C.-C.; Ulasova, E.; Zheng, J.; Ahmed, M.I.; Chen, Y.; Bamman, M.; Ballinger, S.; Darley-Usmar, V.; et al. Novel insights into interactions between mitochondria and xanthine oxidase in acute cardiac volume overload. Free Radic. Biol. Med. 2011, 51, 1975-1984. [CrossRef]

80. Watanabe, K.; Watanabe, T.; Otaki, Y.; Shishido, T.; Murase, T.; Nakamura, T.; Kato, S.; Tamura, H.; Nishiyama, S.; Takahashi, H.; et al. Impact of plasma xanthine oxidoreductase activity in patients with heart failure with preserved ejection fraction. ESC Heart Fail. 2020, 7, 1735-1743. [CrossRef]

81. Semenza, G.L. Hypoxia-Inducible Factor 1 and Cardiovascular Disease. Annu. Rev. Physiol. 2014, 76, 39-56. [CrossRef]

82. Massion, P.B.; Balligand, J.-L. Relevance of nitric oxide for myocardial remodeling. Curr. Heart Fail. Rep. 2007, 4, 18-25. [CrossRef]

83. Soskić, S.S.; Dobutović, B.D.; Sudar, E.M.; Obradović, M.M.; Nikolić, D.M.; Djordjevic, J.D.; Radak, D.J.; Mikhailidis, D.P.; Isenović, E.R. Regulation of Inducible Nitric Oxide Synthase (iNOS) and its Potential Role in Insulin Resistance, Diabetes and Heart Failure. Open Cardiovasc. Med. J. 2011, 5, 153-163. [CrossRef]

84. Marino, A.; Hausenloy, D.J.; Andreadou, I.; Horman, S.; Bertrand, L.; Beauloye, C. AMP-activated protein kinase: A remarkable contributor to preserve a healthy heart against ROS injury. Free Radic. Biol. Med. 2021, 166, 238-254. [CrossRef] [PubMed]

85. North, B.J.; Sinclair, D.A. The Intersection Between Aging and Cardiovascular Disease. Circ. Res. 2012, 110, 1097-1108. [CrossRef]

86. Finkel, T.; Deng, C.-X.; Mostoslavsky, R. Recent progress in the biology and physiology of sirtuins. Nature 2009, 460, 587-591. [CrossRef] [PubMed]

87. Wang, T.; Cao, Y.; Zheng, Q.; Tu, J.; Zhou, W.; He, J.; Zhong, J.; Chen, Y.; Wang, J.; Cai, R.; et al. SENP1-Sirt3 Signaling Controls Mitochondrial Protein Acetylation and Metabolism. Mol. Cell 2019, 75, 823-834.e5. [CrossRef] 
88. Koentges, C.; Cimolai, M.C.; Pfeil, K.; Wolf, D.; Marchini, T.O.; Tarkhnishvili, A.; Hoffmann, M.M.; Odening, K.E.; Diehl, P.; Mühlen, C.V.Z.; et al. Impaired SIRT3 activity mediates cardiac dysfunction in endotoxemia by calpain-dependent disruption of ATP synthesis. J. Mol. Cell. Cardiol. 2019, 133, 138-147. [CrossRef] [PubMed]

89. Sundaresan, N.R.; Gupta, M.; Kim, G.; Rajamohan, S.B.; Isbatan, A.; Gupta, M.P. Sirt3 blocks the cardiac hypertrophic response by augmenting Foxo3a-dependent antioxidant defense mechanisms in mice. J. Clin. Investig. 2009, 119, 2758-2771. [CrossRef]

90. Khalil, H.; Kanisicak, O.; Prasad, V.; Correll, R.N.; Fu, X.; Schips, T. Fibroblast-specific TGF- $\beta$-Smad2/3 signaling underlies cardiac fibrosis. J. Clin. Investig. 2017, 127, 3770-3783. [CrossRef]

91. Luo, K.; Huang, W.; Tang, S. Sirt3 enhances glioma cell viability by stabilizing Ku70-BAX interaction. OncoTargets Ther. 2018, 11, 7559-7567. [CrossRef]

92. Tseng, A.H.; Shieh, S.-S.; Wang, D.L. SIRT3 deacetylates FOXO3 to protect mitochondria against oxidative damage. Free Radic. Biol. Med. 2013, 63, 222-234. [CrossRef] [PubMed]

93. Bergaggio, E.; Riganti, C.; Garaffo, G.; Vitale, N.; Mereu, E.; Bandini, C.; Pellegrino, E.; Pullano, V.; Omedè, P.; Todoerti, K.; et al. IDH2 inhibition enhances proteasome inhibitor responsiveness in hematological malignancies. Blood 2019, 133, 156-167. [CrossRef]

94. Peoples, J.N.; Saraf, A.; Ghazal, N.; Pham, T.T.; Kwong, J.Q. Mitochondrial dysfunction and oxidative stress in heart disease. Exp. Mol. Med. 2019, 51, 1-13. [CrossRef] [PubMed]

95. Anderson, E.J.; Rodriguez, E.; Anderson, C.A.; Thayne, K.; Chitwood, W.R.; Kypson, A.P. Increased propensity for cell death in diabetic human heart is mediated by mitochondrial-dependent pathways. Am. J. Physiol. Circ. Physiol. 2011, 300, H118-H124. [CrossRef] [PubMed]

96. Brand, M.D. The sites and topology of mitochondrial superoxide production. Exp. Gerontol. 2010, 45, 466-472. [CrossRef] [PubMed]

97. Sinha, K.; Das, J.; Pal, P.B.; Sil, P.C. Oxidative stress: The mitochondria-dependent and mitochondria-independent pathways of apoptosis. Arch. Toxicol. 2013, 87, 1157-1180. [CrossRef] [PubMed]

98. Bensaad, K.; Cheung, E.C.; Vousden, K.H. Modulation of intracellular ROS levels by TIGAR controls autophagy. EMBO J. 2009, 28, 3015-3026. [CrossRef]

99. Morgan, M.J.; Liu, Z.G. Reactive oxygen species in TNFalpha-induced signaling and cell death. Mol. Cells 2010, 30, 1-12. [CrossRef]

100. Anderson, E.J.; Efird, J.T.; Davies, S.W.; O’Neal, W.T.; Darden, T.M.; Thayne, K.A.; Katunga, L.A.; Kindell, L.C.; Ferguson, T.B.; Anderson, C.A.; et al. Monoamine Oxidase is a Major Determinant of Redox Balance in Human Atrial Myocardium and is Associated with Postoperative Atrial Fibrillation. J. Am. Heart Assoc. 2014, 3, e000713. [CrossRef]

101. Santin, Y.; Sicard, P.; Vigneron, F.; Guilbeau-Frugier, C.; Dutaur, M.; Lairez, O.; Couderc, B.; Manni, D.; Korolchuk, V.I.; Lezoualc'H, F.; et al. Oxidative Stress by Monoamine Oxidase-A Impairs Transcription Factor EB Activation and Autophagosome Clearance, Leading to Cardiomyocyte Necrosis and Heart Failure. Antioxid. Redox Signal. 2016, 25, 10-27. [CrossRef]

102. Deshwal, S.; Di Sante, M.; Di Lisa, F.; Kaludercic, N. Emerging role of monoamine oxidase as a therapeutic target for cardiovascular disease. Curr. Opin. Pharmacol. 2017, 33, 64-69. [CrossRef] [PubMed]

103. Pchejetski, D.; Kunduzova, O.; Dayon, A.; Calise, D.; Seguelas, M.-H.; Leducq, N.; Seif, I.; Parini, A.; Cuvillier, O. Oxidative Stress-Dependent Sphingosine Kinase-1 Inhibition Mediates Monoamine Oxidase A-Associated Cardiac Cell Apoptosis. Circ. Res. 2007, 100, 41-49. [CrossRef]

104. Menazza, S.; Blaauw, B.; Tiepolo, T.; Toniolo, L.; Braghetta, P.; Spolaore, B.; Reggiani, C.; Di Lisa, F.; Bonaldo, P.; Canton, M. Oxidative stress by monoamine oxidases is causally involved in myofiber damage in muscular dystrophy. Hum. Mol. Genet. 2010, 19, 4207-4215. [CrossRef] [PubMed]

105. Molavian, H.; Tonekaboni, A.M.; Kohandel, M.; Sivaloganathan, S. The Synergetic Coupling among the Cellular Antioxidants Glutathione Peroxidase/Peroxiredoxin and Other Antioxidants and its Effect on the Concentration of $\mathrm{H}_{2} \mathrm{O}_{2}$. Sci. Rep. 2015, 5, srep13620. [CrossRef]

106. Aon, M.A.; Stanley, B.A.; Sivakumaran, V.; Kembro, J.M.; O’Rourke, B.; Paolocci, N.; Cortassa, S. Glutathione/thioredoxin systems modulate mitochondrial $\mathrm{H}_{2} \mathrm{O}_{2}$ emission: An experimental-computational study. J. Gen. Physiol. 2012, 139, 479-491. [CrossRef] [PubMed]

107. Ying, W. NAD ${ }^{+} / \mathrm{NADH}$ and $\mathrm{NADP}^{+} / \mathrm{NADPH}$ in cellular functions and cell death: Regulation and biological consequences. Antioxid. Redox Signal 2008, 10, 179-206. [CrossRef]

108. Nickel, A.G.; Von Hardenberg, A.; Hohl, M.; Löffler, J.R.; Kohlhaas, M.; Becker, J.; Reil, J.-C.; Kazakov, A.; Bonnekoh, J.; Stadelmaier, M.; et al. Reversal of Mitochondrial Transhydrogenase Causes Oxidative Stress in Heart Failure. Cell Metab. 2015, 22, $472-484$. [CrossRef]

109. Kohlhaas, M.; Liu, T.; Knopp, A.; Zeller, T.; Ong, M.F.; Böhm, M.; O’Rourke, B.; Maack, C. Elevated Cytosolic Na ${ }^{+}$Increases Mitochondrial Formation of Reactive Oxygen Species in Failing Cardiac Myocytes. Circulation 2010, 121, 1606-1613. [CrossRef]

110. Schulz, E.; Wenzel, P.; Münzel, T.; Daiber, A. Mitochondrial Redox Signaling: Interaction of Mitochondrial Reactive Oxygen Species with Other Sources of Oxidative Stress. Antioxid. Redox Signal. 2014, 20, 308-324. [CrossRef]

111. Wenzel, P.; Müller, J.; Zurmeyer, S.; Schuhmacher, S.; Schulz, E.; Oelze, M.; Pautz, A.; Kawamoto, T.; Wojnowski, L.; Kleinert, H.; et al. ALDH-2 deficiency increases cardiovascular oxidative stress-Evidence for indirect antioxidative properties. Biochem. Biophys. Res. Commun. 2008, 367, 137-143. [CrossRef] [PubMed] 
112. Bahoran, T.; Soobrattee, M.A.; Luximon-Ramma, V.; Aruoma, O.I. Free Radicals and Antioxidants in Cardiovascular Health and Disease. Internet J. Med. Updat. 2006, 1, 24-40. [CrossRef]

113. Sverdlov, A.L.; Ngo, D.T.M.; Colucci, W.S. 8-Oxidative Stress in Heart Failure. In Heart Failure: A Companion to Braunwald's Heart Disease; Elsevier: Philadelphia, PA, USA, 2020; pp. 115-126.e6.

114. De Keulenaer, G.; Brutsaert, D.L. Diastolic and systolic heart failure are distinct phenotypes within the heart failure spectrum. Circulation 2011, 123, 2014. [CrossRef] [PubMed]

115. Nishihara, T.; Tokitsu, T.; Sueta, D.; Oike, F.; Takae, M.; Fujisue, K.; Usuku, H.; Ito, M.; Kanazawa, H.; Araki, S.; et al. Clinical significance of reactive oxidative metabolites in patients with heart failure with reduced left ventricular ejection fraction. J. Card. Fail. 2020, 27, 57-66. [CrossRef]

116. Hummel, S.L.; Seymour, E.M.; Brook, R.D.; Kolias, T.J.; Sheth, S.S.; Rosenblum, H.R.; Wells, J.M.; Weder, A.B. Low-Sodium Dietary Approaches to Stop Hypertension Diet Reduces Blood Pressure, Arterial Stiffness, and Oxidative Stress in Hypertensive Heart Failure with Preserved Ejection Fraction. Hypertension 2012, 60, 1200-1206. [CrossRef]

117. Chaanine, A.H.; Kohlbrenner, E.; Gamb, S.I.; Guenzel, A.J.; Klaus, K.; Fayyaz, A.U.; Nair, K.S.; Hajjar, R.J.; Redfield, M.M. FOXO3a regulates BNIP3 and modulates mitochondrial calcium, dynamics, and function in cardiac stress. Am. J. Physiol. Circ. Physiol. 2016, 311, H1540-H1559. [CrossRef]

118. Chaanine, A.H. Morphological Stages of Mitochondrial Vacuolar Degeneration in Phenylephrine-Stressed Cardiac Myocytes and in Animal Models and Human Heart Failure. Medicina 2019, 55, 239. [CrossRef]

119. Chaanine, A.H.; Joyce, L.D.; Stulak, J.M.; Maltais, S.; Joyce, D.L.; Dearani, J.A.; Klaus, K.; Nair, K.S.; Hajjar, R.J.; Redfield, M.M. Mitochondrial Morphology, Dynamics, and Function in Human Pressure Overload or Ischemic Heart Disease with Preserved or Reduced Ejection Fraction. Circ. Heart Fail. 2019, 12, e005131. [CrossRef]

120. Terman, A.; Kurz, T.; Gustafsson, B.; Brunk, U.T. The Involvement of Lysosomes in Myocardial Aging and Disease. Curr. Cardiol. Rev. 2008, 4, 107-115. [CrossRef]

121. Leboucher, G.P.; Tsai, Y.C.; Yang, M.; Shaw, K.C.; Zhou, M.; Veenstra, T.D.; Glickman, M.H.; Weissman, A.M. Stress-Induced Phosphorylation and Proteasomal Degradation of Mitofusin 2 Facilitates Mitochondrial Fragmentation and Apoptosis. Mol. Cell 2012, 47, 547-557. [CrossRef]

122. Chaanine, A.; LeJemtel, T.; Delafontaine, P. Mitochondrial Pathobiology and Metabolic Remodeling in Progression to Overt Systolic Heart Failure. J. Clin. Med. 2020, 9, 3582. [CrossRef]

123. Chen, H.C.; Detmer, S.A.; Ewald, A.J.; Griffin, E.E.; Fraser, S.E.; Chan, D.C. Mitofusins Mfn1 and Mfn2 coordinately regulate mitochondrial fusion and are essential for embryonic development. J. Cell Biol. 2003, 160, 189-200. [CrossRef] [PubMed]

124. Cipolat, S.; De Brito, O.M.; Dal Zilio, B.; Scorrano, L. OPA1 requires mitofusin 1 to promote mitochondrial fusion. Proc. Natl. Acad. Sci. USA 2004, 101, 15927-15932. [CrossRef] [PubMed]

125. Chang, C.-R.; Blackstone, C. Dynamic regulation of mitochondrial fission through modification of the dynamin-related protein Drp1. Ann. N. Y. Acad. Sci. 2010, 1201, 34-39. [CrossRef] [PubMed]

126. Varanita, T.; Soriano, M.E.; Romanello, V.; Zaglia, T.; Quintana-Cabrera, R.; Semenzato, M.; Menabò, R.; Costa, V.; Civiletto, G.; Pesce, P.; et al. The Opa1-Dependent Mitochondrial Cristae Remodeling Pathway Controls Atrophic, Apoptotic, and Ischemic Tissue Damage. Cell Metab. 2015, 21, 834-844. [CrossRef]

127. Landes, T.; Emorine, L.J.; Courilleau, D.; Rojo, M.; Belenguer, P.; Arnauné-Pelloquin, L. The BH3-only Bnip3 binds to the dynamin Opa1 to promote mitochondrial fragmentation and apoptosis by distinct mechanisms. EMBO Rep. 2010, 11, 459-465. [CrossRef]

128. Nan, J.; Zhu, W.; Rahman, M.; Liu, M.; Li, D.; Su, S.; Zhang, N.; Hu, X.; Yu, H.; Gupta, M.P.; et al. Molecular regulation of mitochondrial dynamics in cardiac disease. Biochim. Biophys. Acta Mol. Cell Res. 2017, 1864, 1260-1273. [CrossRef]

129. Chaanine, A.H.; Jeong, D.; Liang, L.; Chemaly, E.R.; Fish, K.; Gordon, R.E.; Hajjar, R.J. JNK modulates FOXO3a for the expression of the mitochondrial death and mitophagy marker BNIP3 in pathological hypertrophy and in heart failure. Cell Death Dis. 2012, 3, e265. [CrossRef]

130. Aoki, H.; Kang, P.M.; Hampe, J.; Yoshimura, K.; Noma, T.; Matsuzaki, M.; Izumo, S. Direct Activation of Mitochondrial Apoptosis Machinery by c-Jun N-terminal Kinase in Adult Cardiac Myocytes. J. Biol. Chem. 2002, 277, 10244-10250. [CrossRef]

131. Chang, C.-R.; Blackstone, C. Cyclic AMP-dependent Protein Kinase Phosphorylation of Drp1 Regulates Its GTPase Activity and Mitochondrial Morphology. J. Biol. Chem. 2007, 282, 21583-21587. [CrossRef]

132. Pan, X.; Liu, J.; Nguyen, T.; Liu, C.; Sun, J.; Teng, Y. The physiological role of mitochondrial calcium revealed by mice lacking the mitochondrial calcium uniporter (MCU). Nat. Cell Biol. 2013, 15, 1464. [CrossRef] [PubMed]

133. Wu, Y.; Rasmussen, T.P.; Koval, O.M.; Joiner, M.L.A.; Hall, D.D.; Chen, B. The mitochondrial uniporter controls fight or flight heart rate increases. Nat. Commun. 2015, 6, 6081. [CrossRef]

134. Finkel, T.; Menazza, S.; Holmström, K.M.; Parks, R.J.; Liu, J.; Sun, J. The ins and outs of mitochondrial calcium. Circ. Res. 2015, 116, 1810-1819. [CrossRef]

135. Chaanine, A.H.; Gordon, R.E.; Kohlbrenner, E.; Benard, L.; Jeong, D.; Hajjar, R.J. Potential role of BNIP3 in cardiac remodeling, myocardial stiffness, and endoplasmic reticulum: Mitochondrial calcium homeostasis in diastolic and systolic heart failure. Circ. Heart Fail. 2013, 6, 572-583. [CrossRef] [PubMed]

136. Horton, J.L.; Martin, O.J.; Lai, L.; Riley, N.M.; Richards, A.L.; Vega, R.B.; Leone, T.C.; Pagliarini, D.J.; Muoio, D.M.; Bedi, K.C., Jr.; et al. Mitochondrial protein hyperacetylation in the failing heart. JCI Insight 2016, 1, e84897. [CrossRef] [PubMed] 
137. Chen, T.; Liu, J.; Li, N.; Wang, S.; Liu, H.; Li, J. Mouse SIRT3 Attenuates Hypertrophy-Related Lipid Accumulation in the Heart through the Deacetylation of LCAD. PLoS ONE 2015, 10, e0118909. [CrossRef] [PubMed]

138. Cortassa, S.; Juhaszova, M.; Aon, M.A.; Zorov, D.B.; Sollott, S.J. Mitochondrial $\mathrm{Ca}^{2+}$, redox environment and ROS emission in heart failure: Two sides of the same coin? J. Mol. Cell Cardiol. 2021, 151, 113-125. [CrossRef] [PubMed]

139. Nagai, T.; Anzai, T.; Kaneko, H.; Mano, Y.; Anzai, A.; Maekawa, Y. C-reactive protein overexpression exacerbates pressure overload-induced cardiac remodeling through enhanced inflammatory response. Hypertension 2011, 57, 208-215. [CrossRef]

140. Kobayashi, S.; Inoue, N.; Ohashi, Y.; Terashima, M.; Matsui, K.; Mori, T. Interaction of oxidative stress and inflammatory response in coronary plaque instability: Important role of C-reactive protein. Arterioscler. Thromb. Vasc. Biol. 2003, 23, 1398-1404. [CrossRef]

141. Paulus, W.J.; Tschöpe, C. A novel paradigm for heart failure with preserved ejection fraction: Comorbidities drive myocardial dysfunction and remodeling through coronary microvascular endothelial inflammation. J. Am. Coll. Cardiol. 2013, 62, 263-271. [CrossRef]

142. Simmonds, S.J.; Cuijpers, I.; Heymans, S.; Jones, E.A.V. Cellular and Molecular Differences between HFpEF and HFrEF: A Step Ahead in an Improved Pathological Understanding. Cells 2020, 9, 242. [CrossRef]

143. Katayama, Y.; Battista, M.; Kao, W.-M.; Hidalgo, A.; Peired, A.; Thomas, S.A.; Frenette, P.S. Signals from the Sympathetic Nervous System Regulate Hematopoietic Stem Cell Egress from Bone Marrow. Cell 2006, 124, 407-421. [CrossRef] [PubMed]

144. Dutta, P.; Nahrendorf, M. Monocytes in myocardial infarction. Arterioscler. Thromb. Vasc. Biol. 2015, 35, 1066-1070. [CrossRef] [PubMed]

145. Noll, N.A.; Lal, H.; Merryman, W.D. Mouse Models of Heart Failure with Preserved or Reduced Ejection Fraction. Am. J. Pathol. 2020, 190, 1596-1608. [CrossRef] [PubMed]

146. Li, X.; Liu, J.; Lu, Q.; Ren, D.; Sun, X.; Rousselle, T.; Tan, Y.; Li, J. AMPK: A therapeutic target of heart failure-Not only metabolism regulation. Biosci. Rep. 2019, 39, BSR20181767. [CrossRef]

147. Kanwar, M.; Walter, C.; Clarke, M.; Aponte, M. Targeting heart failure with preserved ejection fraction: Current status and future prospects. Vasc. Health Risk Manag. 2016, 12, 129-141. [CrossRef]

148. Hamdani, N.; Franssen, C.; Lourenço, A.; Falca o-Pires, I.; Fontoura, D.; Leite, S. Myocardial titin hypophosphorylation importantly contributes to heart failure with preserved ejection fraction in a rat metabolic risk model. Circ. Heart Fail. 2013, 6, 1239-1249. [CrossRef]

149. Pacher, P.; Beckman, J.S.; Liaudet, L. Nitric Oxide and Peroxynitrite in Health and Disease. Physiol. Rev. 2007, 87, 315-424. [CrossRef]

150. Ben-Nun, D.; Buja, L.M.; Fuentes, F. Prevention of heart failure with preserved ejection fraction (HFpEF): Reexamining microRNA21 inhibition in the era of oligonucleotide-based therapeutics. Cardiovasc. Pathol. 2020, 49, 107243. [CrossRef]

151. Collier, P.; Watson, C.J.; Voon, V.; Phelan, D.; Jan, A.; Mak, G. Can emerging biomarkers of myocardial remodelling identify asymptomatic hypertensive patients at risk for diastolic dysfunction and diastolic heart failure? Eur. J. Heart Fail. 2011, 13, 1087-1095. [CrossRef]

152. Willis, M.S.; Patterson, C. Proteotoxicity and cardiac dysfunction-Alzheimer's disease of the heart? N. Engl. J. Med. 2013, 368, 455-464. [CrossRef] [PubMed]

153. Taube, A.; Schlich, R.; Sell, H.; Eckardt, K.; Eckel, J. Inflammation and metabolic dysfunction: Links to cardiovascular diseases Am. J. Physiol. Circ. Physiol. 2012, 302, H2148-H2165. [CrossRef]

154. Jelic, S.; Lederer, D.J.; Adams, T.; Padeletti, M.; Colombo, P.C.; Factor, P.H.; Le Jemtel, T.H. Vascular Inflammation in Obesity and Sleep Apnea. Circulation 2010, 121, 1014-1021. [CrossRef] [PubMed]

155. MacDougall, I.C.; Canaud, B.; De Francisco, A.L.; Filippatos, G.; Ponikowski, P.; Silverberg, D.; Van Veldhuisen, D.J.; Anker, S.D. Beyond the cardiorenal anaemia syndrome: Recognizing the role of iron deficiency. Eur. J. Heart Fail. 2012, 14, 882-886. [CrossRef] [PubMed]

156. Matsubara, J.; Sugiyama, S.; Nozaki, T.; Sugamura, K.; Konishi, M.; Ohba, K.; Matsuzawa, Y.; Akiyama, E.; Yamamoto, E.; Sakamoto, K.; et al. Pentraxin 3 Is a New Inflammatory Marker Correlated with Left Ventricular Diastolic Dysfunction and Heart Failure with Normal Ejection Fraction. J. Am. Coll. Cardiol. 2011, 57, 861-869. [CrossRef] [PubMed]

157. Shah, K.B.; Kop, W.J.; Christenson, R.H.; Diercks, D.B.; Henderson, S.; Hanson, K.; Li, S.-Y.; Defilippi, C.R. Prognostic Utility of ST2 in Patients with Acute Dyspnea and Preserved Left Ventricular Ejection Fraction. Clin. Chem. 2011, 57, 874-882. [CrossRef]

158. Griendling, K.K.; Sorescu, D.; Ushio-Fukai, M. NAD(P)H oxidase: Role in cardiovascular biology and disease. Circ. Res. 2000, 86, 494-501. [CrossRef]

159. Van Heerebeek, L.; Hamdani, N.; Falcão-Pires, I.; Leite-Moreira, A.F.; Begieneman, M.P.V.; Bronzwaer, J.G.F.; van der Velden, J.; Stienen, G.J.; Laarman, G.J.; Somsen, A.; et al. Low myocardial protein kinase G activity in heart failure with preserved ejection fraction. Circulation 2012, 126, 830-839. [CrossRef]

160. Westermann, D.; Lindner, D.; Kasner, M.; Zietsch, C.; Savvatis, K.; Escher, F.; von Schlippenbach, J.; Skurk, C.; Steendijk, P.; Riad, A.; et al. Cardiac Inflammation Contributes to Changes in the Extracellular Matrix in Patients with Heart Failure and Normal Ejection Fraction. Circ. Heart Fail. 2011, 4, 44-52. [CrossRef]

161. Dorsch, M.F.; Lawrance, R.A.; Sapsford, R.J.; Durham, N.; Oldham, J.; Greenwood, D.C.; Jackson, B.M.; Morrell, C.; Robinson M.B.; Hall, A.S. Poor prognosis of patients presenting with symptomatic myocardial infarction but without chest pain. Heart 2001, 86, 494-498. [CrossRef] 
162. Zhang, M.; Shah, A.M. ROS signalling between endothelial cells and cardiac cells. Cardiovasc. Res. 2014, 102, 249-257. [CrossRef] [PubMed]

163. Paulus, W.J.; Vantrimpont, P.J.; Shah, A.M. Paracrine Coronary Endothelial Control of Left Ventricular Function in Humans. Circulation 1995, 92, 2119-2126. [CrossRef]

164. Denninger, J.W.; Marletta, M.A. Guanylate cyclase and the .NO/cGMP signaling pathway. Biochim. Biophys. Acta 1999, 1411, 334-350. [CrossRef]

165. Cerra, M.; Pellegrino, D. Cardiovascular cGMP-generating systems in physiological and pathological conditions. Curr. Med. Chem. 2007, 14, 585-599. [CrossRef]

166. Tsai, E.J.; Kass, D.A. Cyclic GMP signaling in cardiovascular pathophysiology and therapeutics. Pharmacol. Ther. 2009, 122, 216-238. [CrossRef] [PubMed]

167. Hobbs, A.J.; Stasch, J.P. Soluble Guanylate Cyclase: Allosteric Activation and Redox Regulation. Nitric Oxide 2010, 1, 301-326.

168. Hamdani, N.; Bishu, K.G.; Von Frieling-Salewsky, M.; Redfield, M.M.; Linke, W.A. Deranged myofilament phosphorylation and function in experimental heart failure with preserved ejection fraction. Cardiovasc. Res. 2012, 97, 464-471. [CrossRef]

169. Bishu, K.G.; Hamdani, N.; Mohammed, S.F.; Kruger, M.; Ohtani, T.; Ogut, O.; Brozovich, F.V.; Burnett, J.C., Jr.; Linke, W.A.; Redfield, M.M. Sildenafil and B-Type Natriuretic Peptide Acutely Phosphorylate Titin and Improve Diastolic Distensibility In Vivo. Circulation 2011, 124, 2882-2891. [CrossRef]

170. Lyle, M.A.; Brozovich, F.V. HFpEF, a Disease of the Vasculature: A Closer Look at the Other Half. Mayo Clin. Proc. 2018, 93, 1305-1314. [CrossRef]

171. Lyle, M.A.; Alabdaljabar, M.S.; Han, Y.S.; Brozovich, F.V. The vasculature in HFpEF vs HFrEF: Differences in contractile protein expression produce distinct phenotypes. Heliyon 2019, 6, e03129. [CrossRef]

172. Schiattarella, G.G.; Altamirano, F.; Tong, D.; French, K.M.; Villalobos, E.; Kim, S.Y.; Luo, X.; Jiang, N.; May, H.I.; Wang, Z.V.; et al. Nitrosative stress drives heart failure with preserved ejection fraction. Nature 2019, 568, 351-356. [CrossRef] [PubMed]

173. Jiang, D.; Niwa, M.; Koong, A.C. Targeting the IRE1 $\alpha-X B P 1$ branch of the unfolded protein response in human diseases. Semin. Cancer Biol. 2015, 33, 48-56. [CrossRef] [PubMed]

174. Ventura-Clapier, R.; Garnier, A.; Veksler, V.; Joubert, F. Bioenergetics of the failing heart. Biochim. Biophys. Acta Mol. Cell Res. 2011, 1813, 1360-1372. [CrossRef] [PubMed]

175. Lopaschuk, G.D.; Ussher, J.R.; Folmes, C.D.L.; Jaswal, J.S.; Stanley, W.C. Myocardial fatty acid metabolism in health and disease Physiol. Rev. 2010, 90, 207-258. [CrossRef]

176. Fillmore, N.; Levasseur, J.L.; Fukushima, A.; Wagg, C.S.; Wang, W.; Dyck, J.R.B.; Lopaschuk, G.D. Uncoupling of glycolysis from glucose oxidation accompanies the development of heart failure with preserved ejection fraction. Mol. Med. 2018, $24,1-12$. [CrossRef]

177. Mori, J.; Basu, R.; McLean, B.A.; Das, S.K.; Zhang, L.; Patel, V.B. Agonist-induced hypertrophy and diastolic dysfunction are associated with selective reduction in glucose oxidation: A metabolic contribution to heart failure with normal ejection fraction. Circ. Heart Fail. 2012, 5, 493-503. [CrossRef]

178. Briston, T.; Roberts, M.; Lewis, S.; Powney, B.; Staddon, J.M.; Szabadkai, G.; Duchen, M.R. Mitochondrial permeability transition pore: Sensitivity to opening and mechanistic dependence on substrate availability. Sci. Rep. 2017, 7, 10492. [CrossRef]

179. Miranda-Silva, D.; Wüst, R.C.I.; Conceição, G.; Gonçalves-Rodrigues, P.; Gonçalves, N.; Gonçalves, A.; Kuster, D.W.D.; LeiteMoreira, A.F.; van der Velden, J.; Beleza, J.M.D.S.; et al. Disturbed cardiac mitochondrial and cytosolic calcium handling in a metabolic risk-related rat model of heart failure with preserved ejection fraction. Acta Physiol. 2019, 228, e13378. [CrossRef]

180. Kraigher-Krainer, E.; Shah, A.M.; Gupta, D.K.; Santos, A.; Claggett, B.; Pieske, B.; Zile, M.; Voors, A.A.; Lefkowitz, M.P.; Packer, M.; et al. Impaired Systolic Function by Strain Imaging in Heart Failure with Preserved Ejection Fraction. J. Am. Coll. Cardiol. 2013, 63, 447-456. [CrossRef]

181. Lee, D.I.; Zhu, G.; Sasaki, T.; Cho, G.-S.; Hamdani, N.; Holewinski, R.J.; Jo, S.-H.; Danner, T.; Zhang, M.; Rainer, P.P.; et al. Phosphodiesterase 9A controls nitric-oxide-independent cGMP and hypertrophic heart disease. Nature 2015, 519, $472-476$. [CrossRef]

182. Wang, L.; Huang, Z.; Huang, W.; Chen, X.; Shan, P.; Zhong, P.; Khan, Z.; Wang, J.; Fang, Q.; Liang, G.; et al. Inhibition of epidermal growth factor receptor attenuates atherosclerosis via decreasing inflammation and oxidative stress. Sci. Rep. 2017, 7, 45917. [CrossRef]

183. Zaha, V.; Young, L.H. AMP-Activated Protein Kinase Regulation and Biological Actions in the Heart. Circ. Res. 2012, 111, 800-814. [CrossRef]

184. Jeon, S.-M. Regulation and function of AMPK in physiology and diseases. Exp. Mol. Med. 2016, 48, e245. [CrossRef]

185. Reichert, K.; Pereira do Carmo, H.R.; Galluce Torina, A.; Diógenes de Carvalho, D.; Carvalho Sposito, A.; De Souza Vilarinho, K.A. Atorvastatin Improves Ventricular Remodeling after Myocardial Infarction by Interfering with Collagen Metabolism. PLoS ONE 2016, 11, e0166845. [CrossRef] [PubMed]

186. Di Napoli, P.; Taccardi, A.A.; Barsotti, A. Long term cardioprotective action of trimetazidine and potential effect on the inflammatory process in patients with ischaemic dilated cardiomyopathy. Heart 2005, 91, 161-165. [CrossRef] [PubMed]

187. Lan, F.; Weikel, K.A.; Cacicedo, J.M.; Ido, Y. Resveratrol-Induced AMP-Activated Protein Kinase Activation Is Cell-Type Dependent: Lessons from Basic Research for Clinical Application. Nutrients 2017, 9, 751. [CrossRef] 
188. Wang, L.; Quan, N.; Sun, W.; Chen, X.; Cates, C.; Rousselle, T.; Zhou, X.; Zhao, X.; Li, J. Cardiomyocyte-specific deletion of Sirt1 gene sensitizes myocardium to ischaemia and reperfusion injury. Cardiovasc. Res. 2018, 114, 805-821. [CrossRef] [PubMed]

189. Li, H.; Xia, N.; Förstermann, U. Cardiovascular effects and molecular targets of resveratrol. Nitric Oxide 2012, 26, 102-110. [CrossRef]

190. Senni, M.; Mcmurray, J.; Wachter, R.; McIntyre, H.F.; Reyes, A.; Majercak, I.; Andreka, P.; Shehova-Yankova, N.; Anand, I.; Yilmaz, M.B.; et al. Initiating sacubitril/valsartan (LCZ696) in heart failure: Results of TITRATION, a double-blind, randomized comparison of two uptitration regimens. Eur. J. Heart Fail. 2016, 18, 1193-1202. [CrossRef] [PubMed]

191. Baruch, L.; Anand, I.; Cohen, I.S.; Ziesche, S.; Judd, D.; Cohn, J.N. Augmented Short- and Long-Term Hemodynamic and Hormonal Effects of an Angiotensin Receptor Blocker Added to Angiotensin Converting Enzyme Inhibitor Therapy in Patients with Heart Failure. Circulation 1999, 99, 2658-2664. [CrossRef]

192. McMurray, J.J.; Packer, M.; Desai, A.S.; Gong, J.; Lefkowitz, M.P.; Rizkala, A.R.; Rouleau, J.L.; Shi, V.C.; Solomon, S.D.; Swedberg, K. Angiotensin-neprilysin inhibition versus enalapril in heart failure. N. Engl. J. Med. 2014, 371, 132-133. [CrossRef] [PubMed]

193. Mazza, A.; Torin, G.; Schiavon, L.; Rossetti, C.; Cuppini, S. Role of sacubitril/valsartan in the treatment of chronic heart failure with reduced ejection fraction in elderly hypertensives with comorbidity: From clinical trials to real world. J. Hypertens. 2021, 39 (Suppl. S1), e279. [CrossRef]

194. Lund, L.H.; Claggett, B.; Liu, J.; Lam, C.S.; Jhund, P.; Rosano, G.M.; Swedberg, K.; Yusuf, S.; Granger, C.B.; Pfeffer, M.A.; et al Heart failure with mid-range ejection fraction in CHARM: Characteristics, outcomes and effect of candesartan across the entire ejection fraction spectrum. Eur. J. Heart Fail. 2018, 20, 1230-1239. [CrossRef]

195. D’Elia, E.; Iacovoni, A.; Vaduganathan, M.; Lorini, L.F.; Perlini, S.; Senni, M. Neprilysin inhibition in heart failure: Mechanisms and substrates beyond modulating natriuretic peptides. Eur. J. Heart Fail. 2017, 19, 710-717. [CrossRef]

196. Solomon, S.D.; McMurray, J.J.V.; Anand, I.S.; Ge, J.; Lam, C.S.P.; Maggioni, A.P.; Martinez, F.; Packer, M.; Pfeffer, M.A.; Pieske, B.; et al. Angiotensin-Neprilysin Inhibition in Heart Failure with Preserved Ejection Fraction. N. Engl. J. Med. 2019, 381, 1609-1620. [CrossRef]

197. Gori, M.; Volterrani, M.; Piepoli, M.; Senni, M. Angiotensin receptor-neprilysin inhibitor (ARNi): Clinical studies on a new class of drugs. Int. J. Cardiol. 2016, 226, 136-140. [CrossRef]

198. Solomon, S.D.; Zile, M.; Pieske, B.; Voors, A.; Shah, A.; Kraigher-Krainer, E.; Shi, V.; Bransford, T.; Takeuchi, M.; Gong, J.; et al. The angiotensin receptor neprilysin inhibitor LCZ696 in heart failure with preserved ejection fraction: A phase 2 double-blind randomised controlled trial. Lancet 2012, 380, 1387-1395. [CrossRef]

199. Jhund, P.S.; Claggett, B.; Packer, M.; Zile, M.; Voors, A.A.; Pieske, B.; Lefkowitz, M.; Shi, V.; Bransford, T.; McMurray, J.J.V.; et al. Independence of the blood pressure lowering effect and efficacy of the angiotensin receptor neprilysin inhibitor, LCZ696, in patients with heart failure with preserved ejection fraction: An analysis of the PARAMOUNT trial. Eur. J. Heart Fail. 2014, 16, 671-677. [CrossRef]

200. Yancy, C.W.; Jessup, M.; Bozkurt, B.; Butler, J.; Casey, D.E.; Drazner, M.H. 2013 ACCF/AHA guideline for the management of heart failure: Executive summary: A report of the American College of Cardiology Foundation/American Heart Association Task Force on practice guidelines. Circulation 2013, 128, 1810-1852. [CrossRef]

201. Tsao, C.W.; Lyass, A.; Enserro, D.; Larson, M.G.; Ho, J.E.; Kizer, J.R.; Gottdiener, J.S.; Psaty, B.M.; Vasan, R.S. Temporal Trends in the Incidence of and Mortality Associated with Heart Failure with Preserved and Reduced Ejection Fraction. JACC Heart Fail. 2018, 6, 678-685. [CrossRef]

202. Calderon-Montano, J.M.; Burgos-Moron, E.; Perez-Guerrero, C.; Lopez-Lazaro, M. A review on the dietary flavonoid kaempferol Mini Rev. Med. Chem. 2011, 11, 298-344. [CrossRef] [PubMed]

203. Arias, A.K.S.; Martin-Romero, F.J.; Gutiérrez-Merino, C. Kaempferol blocks oxidative stress in cerebellar granule cells and reveals a key role for reactive oxygen species production at the plasma membrane in the commitment to apoptosis. Free Radic. Biol. Med. 2004, 37, 48-61. [CrossRef]

204. Du, Y.; Han, J.; Zhang, H.; Xu, J.; Jiang, L.; Ge, W. Kaempferol Prevents Against Ang II-induced Cardiac Remodeling Through Attenuating Ang II-induced Inflammation and Oxidative Stress. J. Cardiovasc. Pharmacol. 2019, 74, 326-335. [CrossRef] [PubMed]

205. Kelso, G.F.; Porteous, C.M.; Coulter, C.V.; Hughes, G.; Porteous, W.K.; Ledgerwood, E.C. Selective targeting of a redox-active ubiquinone to mitochondria within cells: Antioxidant and antiapoptotic properties. J. Biol. Chem. 2001, 276, 4588-4596. [CrossRef] [PubMed]

206. Murphy, M. Understanding and preventing mitochondrial oxidative damage. Biochem. Soc. Trans. 2016, 44, 1219-1226. [CrossRef]

207. Ribeiro Junior, R.F.; Dabkowski, E.R.; Shekar, K.C.; O'Connell, K.A.; Hecker, P.A.; Murphy, M.P. MitoQ improves mitochondrial dysfunction in heart failure induced by pressure overload. Free Radic. Biol. Med. 2018, 117, 18-29. [CrossRef]

208. Trnka, J.; Blaikie, F.H.; Smith, R.A.; Murphy, M.P. A mitochondria-targeted nitroxide is reduced to its hydroxylamine by ubiquinol in mitochondria. Free Radic. Biol. Med. 2008, 44, 1406-1419. [CrossRef]

209. Tauskela, J.S. MitoQ-A mitochondria-targeted antioxidant. IDrugs 2007, 10, 399-412.

210. Chen, W.; Guo, C.; Jia, Z.; Wang, J.; Xia, M.; Li, C.; Li, M.; Yin, Y.; Tang, X.; Chen, T.; et al. Inhibition of Mitochondrial ROS by MitoQ Alleviates White Matter Injury and Improves Outcomes after Intracerebral Haemorrhage in Mice. Oxid. Med. Cell. Longev. 2020, 2020, 8285065. [CrossRef]

211. Fuentes, E.; Araya-Maturana, R.; Urra, F.A. Regulation of mitochondrial function as a promising target in platelet activationrelated diseases. Free Radic. Biol. Med. 2019, 136, 172-182. [CrossRef] 
212. James, A.M.; Sharpley, M.S.; Manas, A.-R.B.; Frerman, F.E.; Hirst, J.; Smith, R.A.J.; Murphy, M.P. Interaction of the Mitochondriatargeted Antioxidant MitoQ with Phospholipid Bilayers and Ubiquinone Oxidoreductases. J. Biol. Chem. 2007, 282, 14708-14718. [CrossRef] [PubMed]

213. Hirsch, G.A.; Bottomley, P.A.; Gerstenblith, G.; Weiss, R.G. Allopurinol Acutely Increases Adenosine Triphospate Energy Delivery in Failing Human Hearts. J. Am. Coll. Cardiol. 2012, 59, 802-808. [CrossRef] [PubMed]

214. Cingolani, H.E.; Plastino, J.A.; Escudero, E.M.; Mangal, B.; Brown, J.; Pérez, N.G. The Effect of Xanthine Oxidase Inhibition Upon Ejection Fraction in Heart Failure Patients: La Plata Study. J. Card. Fail. 2006, 12, 491-498. [CrossRef]

215. Doehner, W.; Schoene, N.; Rauchhaus, M.; Leyva-Leon, F.; Pavitt, D.V.; Reaveley, D.A. Effects of xanthine oxidase inhibition with allopurinol on endothelial function and peripheral blood flow in hyperuricemic patients with chronic heart failure: Results from 2 placebo-controlled studies. Circulation 2002, 105, 2619-2624. [CrossRef] [PubMed]

216. Ratchford, S.M.; Clifton, H.L.; Gifford, J.R.; LaSalle, D.T.; Thurston, T.S.; Bunsawat, K. Impact of acute antioxidant administration on inflammation and vascular function in heart failure with preserved ejection fraction. Am. J. Physiol. Regul. Integr. Comp. Physiol. 2019, 317, R607-R614. [CrossRef]

217. Hare, J.M.; Mangal, B.; Brown, J.; Fisher, C.; Freudenberger, R.; Colucci, W.; Mann, D.; Liu, P.; Givertz, M.M.; Schwarz, R.P. Impact of Oxypurinol in Patients with Symptomatic Heart Failure: Results of the OPT-CHF Study. J. Am. Coll. Cardiol. 2008, 51, 2301-2309. [CrossRef]

218. Givertz, M.M.; Anstrom, K.J.; Redfield, M.M.; Deswal, A.; Haddad, H.; Butler, J. Effects of Xanthine Oxidase Inhibition in Hyperuricemic Heart Failure Patients: The Xanthine Oxidase Inhibition for Hyperuricemic Heart Failure Patients (EXACT-HF) Study. Circulation 2015, 131, 1763-1771. [CrossRef]

219. Yokota, T.; Fukushima, A.; Kinugawa, S.; Okumura, T.; Murohara, T.; Tsutsui, H. Randomized Trial of Effect of Urate-Lowering Agent Febuxostat in Chronic Heart Failure Patients with Hyperuricemia (LEAF-CHF). Int. Heart J. 2018, 59, 976-982. [CrossRef]

220. Carnicer, R.; Duglan, D.; Ziberna, K.; Recalde, A.; Reilly, S.; Simon, J.N.; Mafrici, S.; Arya, R.; Roselló-Lletí, E.; Chuaiphichai, S.; et al. BH4 Increases nNOS Activity and Preserves Left Ventricular Function in Diabetes. Circ. Res. 2021, 128, 585-601. [CrossRef]

221. Bunsawat, K.; Ratchford, S.M.; Alpenglow, J.K.; Park, S.H.; Jarrett, C.L.; Stehlik, J.; Drakos, S.G.; Richardson, R.S.; Wray, D.W. Chronic antioxidant administration restores macrovascular function in patients with heart failure with reduced ejection fraction. Exp. Physiol. 2020, 105, 1384-1395. [CrossRef]

222. Dey, S.; DeMazumder, D.; Sidor, A.; Brian Foster, D.; O’Rourke, B. Mitochondrial ROS Drive Sudden Cardiac Death and Chronic Proteome Remodeling in Heart Failure. Circ. Res. 2018, 123, 356-371. [CrossRef]

223. Hoshino, A.; Okawa, Y.; Ariyoshi, M.; Kaimoto, S.; Uchihashi, M.; Fukai, K.; Iwai-Kanai, E.; Matoba, S. Oxidative PostTranslational Modifications Develop LONP1 Dysfunction in Pressure Overload Heart Failure. Circ. Heart Fail. 2014, 7, 500-509. [CrossRef]

224. Shiomi, T.; Tsutsui, H.; Matsusaka, H.; Murakami, K.; Hayashidani, S.; Ikeuchi, M.; Wen, J.; Kubota, T.; Utsumi, H.; Takeshita, A. Overexpression of Glutathione Peroxidase Prevents Left Ventricular Remodeling and Failure After Myocardial Infarction in Mice. Circulation 2004, 109, 544-549. [CrossRef]

225. Wang, P.; Chen, H.; Qin, H.; Sankarapandi, S.; Becher, M.W.; Wong, P.C.; Zweier, J.L. Overexpression of human copper, zincsuperoxide dismutase (SOD1) prevents postischemic injury. Proc. Natl. Acad. Sci. USA 1998, 95, 4556-4560. [CrossRef] [PubMed]

226. Qin, F.; Lennon-Edwards, S.; Lancel, S.; Biolo, A.; Siwik, D.A.; Pimentel, D.R. Cardiac-specific overexpression of catalase identifies hydrogen peroxide-dependent and independent-phases of myocardial remodeling, and prevents the progression to overt heart failure in Gaq-overexpressing transgenic mice. Circ. Heart Fail. 2010, 3, 306-313. [CrossRef] [PubMed]

227. Maack, C.; Eschenhagen, T.; Hamdani, N.; Heinze, F.R.; Lyon, A.R.; Manstein, D.J. Treatments targeting inotropy: A position paper of the Committees on Translational Research and Acute Heart Failure of the Heart Failure Association of the European Society of Cardiology. Eur. Heart J. 2019, 40, 3626. [CrossRef] [PubMed]

228. Kaludercic, N.; Carpi, A.; Menabò, R.; Di Lisa, F.; Paolocci, N. Monoamine oxidases (MAO) in the pathogenesis of heart failure and ischemia/reperfusion injury. Biochim. Biophys. Acta Mol. Cell Res. 2011, 1813, 1323-1332. [CrossRef] [PubMed]

229. Bianchi, P.; Pimentel, D.R.; Murphy, M.; Colucci, W.; Parini, A. A new hypertrophic mechanism of serotonin in cardiac myocytes: Receptor-independent ROS generation. FASEB J. 2005, 19, 1-15. [CrossRef]

230. Kaludercic, N.; Takimoto, E.; Nagayama, T.; Feng, N.; Lai, E.W.; Bedja, D.; Chen, K.; Gabrielson, K.L.; Blakely, R.D.; Shih, J.C.; et al Monoamine Oxidase A-Mediated Enhanced Catabolism of Norepinephrine Contributes to Adverse Remodeling and Pump Failure in Hearts with Pressure Overload. Circ. Res. 2010, 106, 193-202. [CrossRef] [PubMed]

231. Di Lisa, F.; Kaludercic, N.; Carpi, A.; Menabò, R.; Giorgio, M. Mitochondrial pathways for ROS formation and myocardial injury: The relevance of p66(Shc) and monoamine oxidase. Basic Res. Cardiol. 2009, 104, 131-139. [CrossRef]

232. Carpi, A.; Menabò, R.; Kaludercic, N.; Pelicci, P.; Di Lisa, F.; Giorgio, M. The cardioprotective effects elicited by p66Shc ablation demonstrate the crucial role of mitochondrial ROS formation in ischemia/reperfusion injury. Biochim. Biophys. Acta Bioenerg. 2009, 1787, 774-780. [CrossRef]

233. Villeneuve, C.; Guilbeau-Frugier, C.; Sicard, P.; Lairez, O.; Ordener, C.; Duparc, T.; De Paulis, D.; Couderc, B.; Spreux-Varoquaux, O.; Tortosa, F.; et al. p53-PGC-1 $\alpha$ Pathway Mediates Oxidative Mitochondrial Damage and Cardiomyocyte Necrosis Induced by Monoamine Oxidase-A Upregulation: Role in Chronic Left Ventricular Dysfunction in Mice. Antioxid. Redox Signal. 2013, 18, 5-18. [CrossRef] 
234. Umbarkar, P.; Singh, S.; Arkat, S.; Bodhankar, S.; Lohidasan, S.; Sitasawad, S.L. Monoamine oxidase-A is an important source of oxidative stress and promotes cardiac dysfunction, apoptosis, and fibrosis in diabetic cardiomyopathy. Free Radic. Biol. Med. 2015, 87, 263-273. [CrossRef] [PubMed]

235. Kaludercic, N.; Carpi, A.; Nagayama, T.; Sivakumaran, V.; Zhu, G.; Lai, E.W.; Bedja, D.; De Mario, A.; Chen, K.; Gabrielson, K.L.; et al. Monoamine Oxidase B Prompts Mitochondrial and Cardiac Dysfunction in Pressure Overloaded Hearts. Antioxid. Redox Signal. 2014, 20, 267-280. [CrossRef] [PubMed]

236. Manni, M.E.; Rigacci, S.; Borchi, E.; Bargelli, V.; Miceli, C.; Giordano, C.; Raimondi, L.; Nediani, C. Monoamine Oxidase Is Overactivated in Left and Right Ventricles from Ischemic Hearts: An Intriguing Therapeutic Target. Oxidative Med. Cell. Longev. 2016, 2016, 4375418. [CrossRef]

237. Sharma, A.; Fonarow, G.C.; Butler, J.; Ezekowitz, J.A.; Felker, G.M. Coenzyme Q10 and Heart Failure: A State-of-the-Art Review. Circ. Heart Fail. 2016, 9, e002639. [CrossRef] [PubMed]

238. Pierce, J.D.; Mahoney, D.E.; Hiebert, J.B.; Thimmesch, A.R.; Diaz, F.J.; Smith, C.; Shen, Q.; Mudaranthakam, D.P.; Clancy, R.L. Study protocol, randomized controlled trial: Reducing symptom burden in patients with heart failure with preserved ejection fraction using ubiquinol and/or D-ribose. BMC Cardiovasc. Disord. 2018, 18, 57. [CrossRef] [PubMed]

239. Bentinger, M.; Tekle, M.; Dallner, G. Coenzyme Q-Biosynthesis and functions. Biochem. Biophys. Res. Commun. 2010, 396, 74-79. [CrossRef]

240. McCarthy, S.; Somayajulu, M.; Sikorska, M.; Borowy-Borowski, H.; Pandey, S. Paraquat induces oxidative stress and neuronal cell death; neuroprotection by water-soluble Coenzyme Q10. Toxicol. Appl. Pharmacol. 2004, 201, 21-31. [CrossRef]

241. Hathcock, J.N.; Shao, A. Risk assessment for coenzyme Q10 (Ubiquinone). Regul. Toxicol. Pharmacol. 2006, 45, 282-288. [CrossRef]

242. Von Hardenberg, A.; Maack, C. Mitochondrial Therapies in Heart Failure. Handb. Exp. Pharmacol. 2017, 243, 491-514. [PubMed]

243. Mortensen, S.A.; Rosenfeldt, F.; Kumar, A.; Dolliner, P.; Filipiak, K.J.; Pella, D. The effect of coenzyme Q10 on morbidity and mortality in chronic heart failure: Results from Q-SYMBIO: A randomized double-blind trial. JACC Heart Fail. 2014, 2, 641-649. [CrossRef]

244. Szeto, H.H. First-in-class cardiolipin-protective compound as a therapeutic agent to restore mitochondrial bioenergetics. J. Cereb. Blood Flow Metab. 2014, 171, 2029-2050. [CrossRef]

245. Bertero, E.; Kutschka, I.; Maack, C.; Dudek, J. Cardiolipin remodeling in Barth syndrome and other hereditary cardiomyopathies. Biochim. Biophys. Acta Mol. Basis Dis. 2020, 1866, 165803. [CrossRef] [PubMed]

246. Su, L.-J.; Zhang, J.-H.; Gomez, H.; Murugan, R.; Hong, X.; Xu, D.; Jiang, F.; Peng, Z.-Y. Reactive Oxygen Species-Induced Lipid Peroxidation in Apoptosis, Autophagy, and Ferroptosis. Oxid. Med. Cell. Longev. 2019, 2019, 5080843. [CrossRef]

247. Yin, H.; Zhu, M. Free radical oxidation of cardiolipin: Chemical mechanisms, detection and implication in apoptosis, mitochondrial dysfunction and human diseases. Free Radic. Res. 2012, 46, 959-974. [CrossRef]

248. Sabbah, H.N.; Gupta, R.C.; Kohli, S.; Wang, M.; Hachem, S.; Zhang, K. Chronic Therapy with Elamipretide (MTP-131), a Novel Mitochondria-Targeting Peptide, Improves Left Ventricular and Mitochondrial Function in Dogs with Advanced Heart Failure. Circ. Heart Fail. 2016, 9, e002206. [CrossRef] [PubMed]

249. Chatfield, K.C.; Sparagna, G.C.; Chau, S.; Phillips, E.K.; Ambardekar, A.V.; Aftab, M.; Mitchell, M.B.; Sucharov, C.C.; Miyamoto, S.D.; Stauffer, B.L. Elamipretide Improves Mitochondrial Function in the Failing Human Heart. JACC Basic Transl. Sci. 2019, 4, 147-157. [CrossRef]

250. Brown, D.A.; Hale, S.L.; Baines, C.; del Rio, C.; Hamlin, R.L.; Yueyama, Y.; Kijtawornrat, A.; Yeh, S.T.; Frasier, C.R.; Stewart, L.M.; et al. Reduction of Early Reperfusion Injury with the Mitochondria-Targeting Peptide Bendavia. J. Cardiovasc. Pharmacol. Ther. 2013, 19, 121-132. [CrossRef]

251. Daubert, M.A.; Yow, E.; Dunn, G.; Marchev, S.; Barnhart, H.; Douglas, P.S.; O'Connor, C.; Goldstein, S.; Udelson, J.E.; Sabbah, H.N. Novel Mitochondria-Targeting Peptide in Heart Failure Treatment: A Randomized, Placebo-Controlled Trial of Elamipretide. Circ. Heart Fail. 2017, 10, e004389. [CrossRef] [PubMed]

252. Butler, J.; Khan, M.S.; Anker, S.D.; Fonarow, G.C.; Kim, R.J.; Nodari, S.; O'Connor, C.M.; Pieske, B.; Pieske-Kraigher, E.; Sabbah, H.N.; et al. Effects of Elamipretide on Left Ventricular Function in Patients with Heart Failure with Reduced Ejection Fraction: The PROGRESS-HF Phase 2 Trial. J. Card. Fail. 2020, 26, 429-437. [CrossRef] [PubMed]

253. Gevaert, A.B.; Boen, J.R.; Segers, V.F.; Van Craenenbroeck, E.M. Heart Failure with Preserved Ejection Fraction: A Review of Cardiac and Noncardiac Pathophysiology. Front. Physiol. 2019, 10, 638. [CrossRef] [PubMed]

254. Lin, E.Q.; Irvine, J.C.; Cao, A.H.; Alexander, A.E.; Love, J.E.; Patel, R.; McMullen, J.R.; Kaye, D.M.; Kemp-Harper, B.K.; Ritchie, R.H. Nitroxyl (HNO) Stimulates Soluble Guanylyl Cyclase to Suppress Cardiomyocyte Hypertrophy and Superoxide Generation. PLoS ONE 2012, 7, e34892. [CrossRef]

255. Sabbah, H.N.; Tocchetti, C.G.; Wang, M.; Daya, S.; Gupta, R.C.; Tunin, R.S.; Mazhari, R.; Takimoto, E.; Paolocci, N.; Cowart, D.; et al. Nitroxyl (HNO). Circ. Heart Fail. 2013, 6, 1250-1258. [CrossRef] [PubMed]

256. Gheorghiade, M.; Greene, S.J.; Filippatos, G.; Erdmann, E.; Ferrari, R.; Levy, P.D.; Maggioni, A.; Nowack, C.; Mebazaa, A.; COMPOSE Investigators and Coordinators. Cinaciguat, a soluble guanylate cyclase activator: Results from the randomized, controlled, phase IIb COMPOSE programme in acute heart failure syndromes. Eur. J. Heart Fail. 2012, 14, 1056-1066. [CrossRef] [PubMed]

257. Ghofrani, H.-A.; Galiè, N.; Grimminger, F.; Grünig, E.; Humbert, M.; Jing, Z.-C. Riociguat for the treatment of pulmonary arterial hypertension. N. Engl. J. Med. 2013, 369, 330-340. [CrossRef] [PubMed] 
258. Pieske, B.; Butler, J.; Filippatos, G.; Lam, C.; Maggioni, A.P.; Ponikowski, P.; Shah, S.; Solomon, S.; Kraigher-Krainer, E.; Samano, E.T.; et al. Rationale and design of the SOluble guanylate Cyclase stimulatoR in heArT failurE Studies (SOCRATES). Eur. J. Heart Fail. 2014, 16, 1026-1038. [CrossRef]

259. Zhazykbayeva, S.; Pabel, S.; Mügge, A.; Sossalla, S.; Hamdani, N. The molecular mechanisms associated with the physiological responses to inflammation and oxidative stress in cardiovascular diseases. Biophys. Rev. 2020, 12, 947-968. [CrossRef] [PubMed]

260. Redfield, M.M.; Borlaug, B.A.; Lewis, G.D.; Mohammed, S.F.; Semigran, M.J.; Lewinter, M.M.; Deswal, A.; Hernandez, A.F.; Lee, K.L.; Braunwald, E.; et al. PhosphdiesteRasE-5 Inhibition to Improve CLinical Status and EXercise Capacity in Diastolic Heart Failure (RELAX) trial: Rationale and design. Circ. Heart Fail. 2012, 5, 653-659. [CrossRef]

261. Corbin, J.D. Mechanisms of action of PDE5 inhibition in erectile dysfunction. Int. J. Impot. Res. 2004, 16, S4-S7. [CrossRef]

262. Lewis, G.D.; Lachmann, J.; Camuso, J.; Lepore, J.J.; Shin, J.; Martinovic, M.E.; Systrom, D.M.; Bloch, K.D.; Semigran, M.J. Sildenafil Improves Exercise Hemodynamics and Oxygen Uptake in Patients with Systolic Heart Failure. Circulation 2007, 115, 59-66. [CrossRef] [PubMed]

263. Guazzi, M.; Vicenzi, M.; Arena, R.; Guazzi, M.D. PDE5 inhibition with sildenafil improves left ventricular diastolic function, cardiac geometry, and clinical status in patients with stable systolic heart failure: Results of a 1-year, prospective, randomized, placebo-controlled study. Circ. Heart Fail. 2011, 4, 8-17. [CrossRef] [PubMed]

264. Guazzi, M.; Vicenzi, M.; Arena, R. Phosphodiesterase 5 inhibition with sildenafil reverses exercise oscillatory breathing in chronic heart failure: A long-term cardiopulmonary exercise testing placebo-controlled study. Eur. J. Heart Fail. 2012, 14, 82-90. [CrossRef] [PubMed]

265. Guazzi, M.; Vicenzi, M.; Arena, R.; Guazzi, M.D. Pulmonary hypertension in heart failure with preserved ejection fraction: A target of phosphodiesterase-5 inhibition in a 1-year study. Circulation 2011, 124, 164-174. [CrossRef]

266. Pinilla-Vera, M.; Hahn, V.S.; Kass, D.A. Leveraging Signaling Pathways to Treat Heart Failure with Reduced Ejection Fraction. Circ. Res. 2019, 124, 1618-1632. [CrossRef]

267. Tocchetti, C.G.; Stanley, B.A.; Murray, C.I.; Sivakumaran, V.; Donzelli, S.; Mancardi, D.; Pagliaro, P.; Gao, W.D.; Van Eyk, J.; Kass, D.A.; et al. Playing with cardiac "redox switches": The "HNO way" to modulate cardiac function. Antioxid. Redox Signal 2011, 114, 1687-1698. [CrossRef]

268. Tita, C.; Gilbert, E.M.; Van Bakel, A.B.; Grzybowski, J.; Haas, G.J.; Jarrah, M.; Dunlap, S.H.; Gottlieb, S.S.; Klapholz, M.; Patel, P.C.; et al. A Phase 2a dose-escalation study of the safety, tolerability, pharmacokinetics and haemodynamic effects of BMS-986231 in hospitalized patients with heart failure with reduced ejection fraction. Eur. J. Heart Fail. 2017, 19, 1321-1332. [CrossRef]

269. Hartman, J.C.; del Rio, C.; Reardon, J.E.; Zhang, K.; Sabbah, H.N. Intravenous Infusion of the Novel HNO Donor BMS-986231 Is Associated with Beneficial Inotropic, Lusitropic, and Vasodilatory Properties in 2 Canine Models of Heart Failure. JACC Basic Transl. Sci. 2018, 3, 625-638. [CrossRef]

270. Felker, G.M.; Borentain, M.; Cleland, J.G.; DeSouza, M.M.; Kessler, P.D.; O'Connor, C.M.; Seiffert, D.; Teerlink, J.R.; Voors, A.A.; McMurray, J.J. Rationale and design for the development of a novel nitroxyl donor in patients with acute heart failure. Eur. J. Heart Fail. 2019, 21, 1022-1031. [CrossRef]

271. Kemp-Harper, B.; Schmidt, H.H.H.W. cGMP in the vasculature. Handb. Exp. Pharmacol. 2009, 191, 447-467.

272. Ivanova, J.; Salama, G.; Clancy, R.M.; Schor, N.F.; Nylander, K.D.; Stoyanovsky, D.A. Formation of nitroxyl and hydroxyl radical in solutions of sodium trioxodinitrate: Effects of $\mathrm{pH}$ and cytotoxicity. J. Biol. Chem. 2003, 278, 42761-42768. [CrossRef] [PubMed]

273. Shiva, S.; Crawford, J.H.; Ramachandran, A.; Ceaser, E.K.; Hillson, T.; Brookes, P.; Patel, R.P.; Darley-Usmar, V.M. Mechanisms of the interaction of nitroxyl with mitochondria. Biochem. J. 2004, 379, 359-366. [CrossRef] [PubMed]

274. Tocchetti, C.G.; Wang, W.; Froehlich, J.P.; Huke, S.; Aon, M.A.; Wilson, G.M.; Di Benedetto, G.; O’Rourke, B.; Gao, W.D.; Wink, D.A.; et al. Nitroxyl Improves Cellular Heart Function by Directly Enhancing Cardiac Sarcoplasmic Reticulum Ca ${ }^{2+} \mathrm{Cycling}$. Circ. Res. 2007, 100, 96-104. [CrossRef] [PubMed]

275. Paolocci, N.; Saavedra, W.F.; Miranda, K.M.; Martignani, C.; Isoda, T.; Hare, J.M.; Espey, M.G.; Fukuto, J.M.; Feelisch, M.; Wink, D.A.; et al. Nitroxyl anion exerts redox-sensitive positive cardiac inotropy in vivo by calcitonin gene-related peptide signaling. Proc. Natl. Acad. Sci. USA 2001, 98, 10463-10468. [CrossRef]

276. Paolocci, N.; Katori, T.; Champion, H.C.; St John, M.E.; Miranda, K.M.; Fukuto, J.M. Positive inotropic and lusitropic effects of HNO/NO- in failing hearts: Independence from beta-adrenergic signaling. Proc. Natl. Acad. Sci. USA 2003, 100, 5537-5542 [CrossRef] [PubMed]

277. Ziolo, M.T.; Kohr, M.J.; Kaludercic, N.; Tocchetti, C.G.; Gao, W.D.; A Kass, D.; Janssen, P.M.L.; Paolocci, N. Nitroxyl enhances myocyte Ca2 transients by exclusively targeting SR Ca ${ }^{2+}$-cycling. Front. Biosci. 2010, E2, 614-626. [CrossRef]

278. Dai, T.; Tian, Y.; Tocchetti, C.G.; Katori, T.; Murphy, A.M.; Kass, D.A.; Paolocci, N.; Gao, W.D. Nitroxyl increases force development in rat cardiac muscle. J. Physiol. 2007, 580, 951-960. [CrossRef]

279. Tocchetti, C.G.; Mercurio, V.; Maack, C. The multifaceted mechanisms of nitroxyl in heart failure: Inodilator or "only" vasodilator? Eur. J. Heart Fail. 2021, 123, 1156-1159. [CrossRef]

280. Hare, J.M. Nitroso-Redox Balance in the Cardiovascular System. N. Engl. J. Med. 2004, 351, 2112-2114. [CrossRef]

281. Münzel, T.; Daiber, A.; Gori, T. More answers to the still unresolved question of nitrate tolerance. Eur. Heart J. 2013, 34, 2666-2673. [CrossRef] 
282. Daiber, A.; Oelze, M.; Coldewey, M.; Kaiser, K.; Huth, C.; Schildknecht, S.; Bachschmid, M.M.; Nazirisadeh, Y.; Ullrich, V.; Mülsch, A.; et al. Hydralazine is a powerful inhibitor of peroxynitrite formation as a possible explanation for its beneficial effects on prognosis in patients with congestive heart failure. Biochem. Biophys. Res. Commun. 2005, 338, 1865-1874. [CrossRef]

283. Münzel, T.; Kurz, S.; Rajagopalan, S.; Thoenes, M.; Berrington, W.R.; A Thompson, J.; A Freeman, B.; Harrison, D.G. Hydralazine prevents nitroglycerin tolerance by inhibiting activation of a membrane-bound NADH oxidase. A new action for an old drug. J. Clin. Investig. 1996, 98, 1465-1470. [CrossRef] [PubMed]

284. Münzel, T.; Steven, S.; Daiber, A. Organic nitrates: Update on mechanisms underlying vasodilation, tolerance and endothelial dysfunction. Vasc. Pharmacol. 2014, 63, 105-113. [CrossRef] [PubMed]

285. Sandner, P. From molecules to patients: Exploring the therapeutic role of soluble guanylate cyclase stimulators. Biol. Chem. 2018, 399, 679-690. [CrossRef] [PubMed]

286. Taylor, A.L.; Ziesche, S.; Yancy, C.; Carson, P.; D'Agostino, R.; Ferdinand, K.; Taylor, M.; Adams, K.; Sabolinski, M.; Worcel, M.; et al. Combination of Isosorbide Dinitrate and Hydralazine in Blacks with Heart Failure. N. Engl. J. Med. 2004, 351, $2049-2057$. [CrossRef]

287. Evgenov, O.V.; Pacher, P.; Schmidt, P.M.; Haskó, G.; Schmidt, H.H.H.W.; Stasch, J.P. NO-independent stimulators and activators of soluble guanylate cyclase: Discovery and therapeutic potential. Nat. Rev. Drug Discov. 2006, 5, 755-768. [CrossRef]

288. Montfort, W.R.; Wales, J.A.; Weichsel, A. Structure and Activation of Soluble Guanylyl Cyclase, the Nitric Oxide Sensor. Antioxid. Redox Signal. 2017, 26, 107-121. [CrossRef]

289. Breitenstein, S.; Roessig, L.; Sandner, P.; Lewis, K.S. Novel sGC Stimulators and sGC Activators for the Treatment of Heart Failure. Handb. Exp. Pharmacol. 2017, 243, 225-247. [CrossRef]

290. Follmann, M.; Ackerstaff, J.; Redlich, G.; Wunder, F.; Lang, D.; Kern, A.; Fey, P.; Griebenow, N.; Kroh, W.; BeckerPelster, E.-M.; et al. Discovery of the Soluble Guanylate Cyclase Stimulator Vericiguat (BAY 1021189) for the Treatment of Chronic Heart Failure. J. Med. Chem. 2017, 60, 5146-5161. [CrossRef]

291. Premer, C.; Kanelidis, A.J.; Hare, J.M.; Schulman, I.H. Rethinking Endothelial Dysfunction as a Crucial Target in Fighting Heart Failure. Mayo Clinic Proc. Innov. Qual. Outcomes 2019, 3, 1-13. [CrossRef]

292. Kolijn, D.; Kovács, Á.; Herwig, M.; Lódi, M.; Sieme, M.; Alhaj, A.; Sandner, P.; Papp, Z.; Reusch, P.H.; Haldenwang, P.; et al. Enhanced Cardiomyocyte Function in Hypertensive Rats with Diastolic Dysfunction and Human Heart Failure Patients After Acute Treatment with Soluble Guanylyl Cyclase (sGC) Activator. Front. Physiol. 2020, 11, 345. [CrossRef]

293. Archer, S.L.; Huang, J.M.; Hampl, V.; Nelson, D.P.; Shultz, P.J.; Weir, E.K. Nitric oxide and cGMP cause vasorelaxation by activation of a charybdotoxin-sensitive K channel by cGMP-dependent protein kinase. Proc. Natl. Acad. Sci. USA 1994, 91, 7583-7587. [CrossRef] [PubMed]

294. Buys, E.; Zimmer, D.; Chickering, J.; Graul, R.; Chien, Y.; Profy, A.; Hadcock, J.; Masferrer, J.; Milne, G. Discovery and development of next generation sGC stimulators with diverse multidimensional pharmacology and broad therapeutic potential. Nitric Oxide 2018, 78, 72-80. [CrossRef]

295. Anker, S.D.; Butler, J.; Filippatos, G.; Ferreira, J.P.; Bocchi, E.; Böhm, M.; Rocca, H.-P.B.; Choi, D.-J.; Chopra, V.; ChuquiureValenzuela, E.; et al. Empagliflozin in Heart Failure with a Preserved Ejection Fraction. N. Engl. J. Med. 2021, 385, $1451-1461$. [CrossRef]

296. Lang, N.N.; Ahmad, F.A.; Cleland, J.G.; O'Connor, C.M.; Teerlink, J.R.; Voors, A.A.; Taubel, J.; Hodes, A.R.; Anwar, M.; Karra, R.; et al. Haemodynamic effects of the nitroxyl donor cimlanod (BMS -986231) in chronic heart failure: A randomized trial. Eur. J. Heart Fail. 2021, 23, 1147-1155. [CrossRef] [PubMed]

297. Gheorghiade, M.; Greene, S.J.; Butler, J.; Filippatos, G.; Lam, C.S.P.; Maggioni, A.P.; Ponikowski, P.; Shah, S.J.; Solomon, S.D.; Kraigher-Krainer, E.; et al. Effect of vericiguat, a soluble guanylate cyclase stimulator, on natriuretic peptide levels in patients with worsening chronic heart failure and reduced ejection fraction: The SOCRATES-REDUCED randomized trial. JAMA 2015, 314, 2251-2262. [CrossRef] [PubMed]

298. Pieske, B.; Maggioni, A.P.; Lam, C.S.; Pieske-Kraigher, E.; Filippatos, G.; Butler, J.; Ponikowski, P.; Shah, S.; Solomon, S.D.; Scalise, A.-V.; et al. Vericiguat in patients with worsening chronic heart failure and preserved ejection fraction: Results of the SOluble guanylate Cyclase stimulatoR in heArT failurE patientS with PRESERVED EF (SOCRATES-PRESERVED) study. Eur. Heart J. 2017, 38, 1119-1127. [CrossRef]

299. Armstrong, P.W.; Lam, C.S.P.; Anstrom, K.J.; Ezekowitz, J.; Hernandez, A.F.; O'Connor, C.M. Effect of Vericiguat vs Placebo on Quality of Life in Patients with Heart Failure and Preserved Ejection Fraction: The VITALITY-HFpEF Randomized Clinical Trial. JAMA 2020, 324, 1512-1521. [CrossRef] [PubMed] 